\title{
The Papoose Flat Pluton of eastern California: a reassessment of its emplacement history in the light of new microstructural and crystallographic fabric observations
}

\author{
R. D. Law, S. S. Morgan, M. Casey, A. G. Sylvester and M. Nyman
}

ABSTRACT: One of the most outstanding apparent examples in $\mathbf{N}$ America of a forcibly emplaced pluton is the Papoose Flat Pluton of eastern California. Sideways expansion of this granitic pluton, during emplacement into a series of Cambrian shelf strata, has been regarded by early workers as resulting in the observed intense crystal plastic deformation of the pluton's mylonitic border facies and surrounding country rocks. This deformation is evidenced by up to $90 \%$ thinning of individual stratigraphic layers within the pluton's metamorphic aureole, although such intense penetrative deformation of the country rocks is not observed outside the aureole.

Previously published quartz c-axis fabrics associated with this deformation (and presented on projection planes oriented perpendicular to lineation) were interpreted as being symmetrical with respect to foliation and lineation, implying almost coaxial deformation histories. Such fabrics could be interpreted as indicating that the pluton evolved by "ballooning" as a result of new magma being intruded into its core during emplacement. However, a major problem with applying the strict ballooning model to the Papoose Flat Pluton is that while oblate strains would be expected to develop in association with a ballooning mechanism, the mylonitic rocks of this elongate WNW-ESE-trending pluton and its aureole are characterised by both a strongly developed foliation, which is concordant with the pluton's margin, and an intense, NW-SE trending, shallow plunging stretching lineation.

Previously published fabrics from the Papoose Flat Pluton and its metamorphic aureole have been rotated on to a projection plane oriented parallel to lineation and perpendicular to foliation. Examination of the fabrics in this projection plane has revealed that they are in fact dominantly asymmetric, and that a constant sense of asymmetry is detected across the pluton, suggesting a consistent (top-to-the-SE) shear-sense. This new interpretation is strongly supported by microstructural and petrofabric analysis of additional L-S tectonites collected, during recent fieldwork, from both the aureole and quartz veins within the pluton's gneissic border facies. Thus mylonite formation around the Papoose Flat Pluton could have involved large-scale consistently oriented translation and associated shearing, rather than passive "blister-like" coaxial deformation associated with pluton ballooning. It should be noted that mylonitic deformation is restricted to the western half of the pluton, features indicative of a more "permitted" emplacement mechanism being found in the eastern portion of the pluton.

The detected top-to-the-SE shear-sense could be interpreted as indicating that the granitic material forming the western part of the pluton was forcibly intruded in a northwestward direction from the pluton source as a nearly solidified wedge beneath a static cover of sedimentary rocks. Alternatively, the detected shear sense could also be interpreted as indicating SE-directed thrusting of the cover rocks over the underlying pluton, the western margin of the pluton suffering intense mylonitic deformation, while the eastern margin was located in a "stress-shadow" region. If this alternative interpretation is correct, then the deformation temperatures indicated by the pattern of quartz c-axis fabrics dictate that thrusting must either be synchronous with pluton emplacement, or at least have commenced during the early stages of pluton cooling.

KEY WORDS: calcite, contact metamorphism, emplacement mechanisms, granite, mylonite, quartz, shear sense, texture goniometry.

In recent years there has been a resurgence of interest in the mechanisms and timing of pluton emplacement relative to regional deformation (e.g. Brun \& Pons 1981; Hutton 1982; Bateman 1984; Castro 1986; Hollister \& Crawford 1986; Courrioux 1987; Guineberteau et al. 1987; Hibbard 1987; Hutton 1988a,b; Paterson \& Tobisch 1988; Paterson et al.

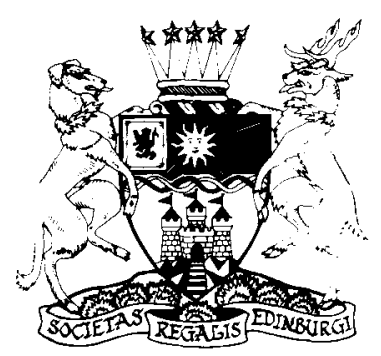

1989; Ramsay 1989; Brun et al. 1990; Paterson et al. 1991a,b). Pluton emplacement mechanisms have traditionally been divided into two basic types: forcible emplacement, including doming, diapirism and ballooning; and "permitted" emplacement, involving stoping, cauldron subsidence and sheeting. Hutton (1988a) argued that the 
critical factor controlling the emplacement mechanism of an individual pluton is the relationship between the rate of buoyant uprise of magma and the rate of tectonic cavity opening. For forcible emplacement, the rate of magma uprise is greater than the rate of tectonic cavity opening, whereas for permitted intrusions, the rate of cavity opening is greater than the rate of magma uprise.

The spectacularly exposed Papoose Flat Pluton of eastern California (Fig. 1) has been regarded as a classical example of a forcibly emplaced pluton (Sylvester et al. 1978). On palinspastic reconstruction (Nelson et al. 1977) the pluton is roughly elliptical-rectangular in plan view. Sideways expansion of the granitic pluton, during emplacement into a series of Cambrian shelf strata, was regarded by Sylvester $\boldsymbol{e t}$ al. (1978) as resulting in the intense crystal plastic deformation of the western half of the pluton's margin and surrounding country rocks. This localised (or blister-like) deformation of the country rock (Sylvester et al. 1978) around the concordantly intruded western part of the pluton caused up to $90 \%$ thinning of individual stratigraphic layers. Mylonitic foliation within the deformation zone defines a concentric pattern about the pluton and is parallel to both bedding and the pluton walls. The grain shape stretching lineation lying within the foliation (Fig. 2) is horizontalgently plunging and, unlike the concentric foliation pattern, is oriented sub-parallel to the long axis of the pluton on palinspastic reconstruction (Nelson et al. 1977). Penetrative

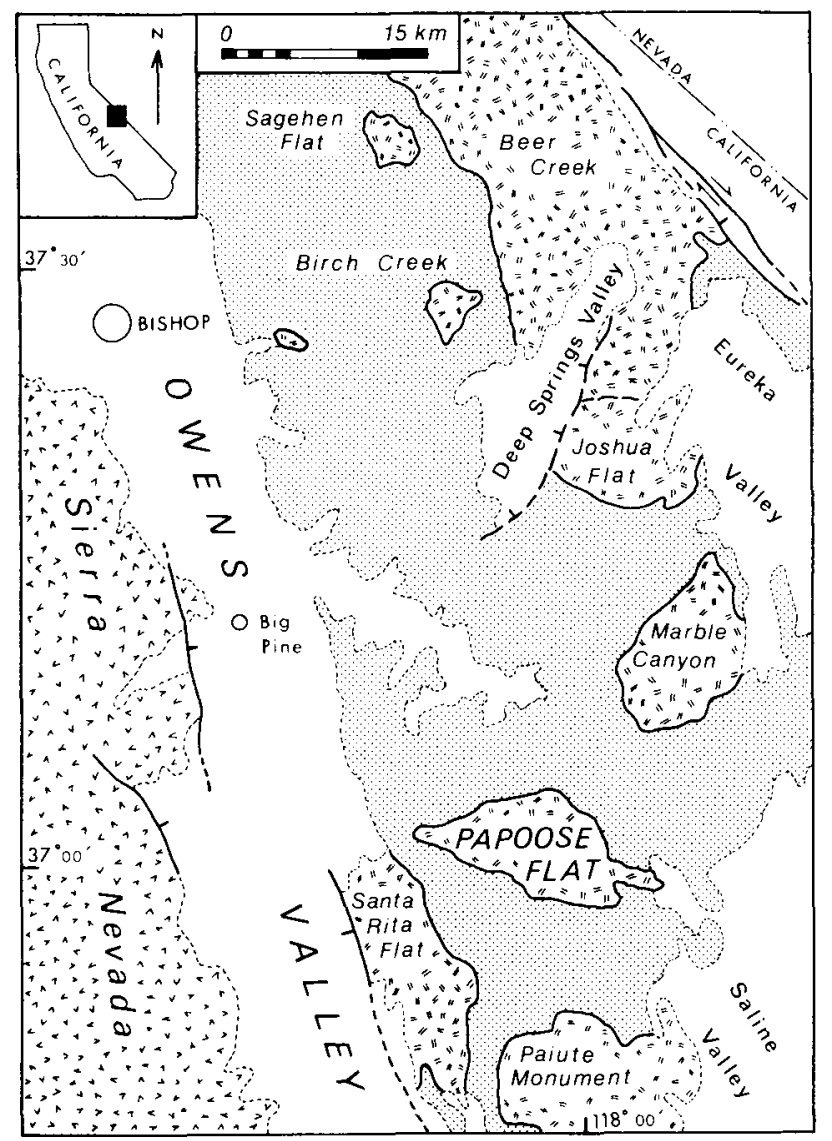

Figure 1 Regional geological setting of the Papoose Flat Pluton and other plutons of the White-Inyo Range (adapted from Sylvester et al. 1978); stippled pattern = pre-plutonic rocks; v-shaped pattern $=$ granitic rocks of the Sierra Nevada, no pattern $=$ Cainozoic volcanic rocks and alluvium; pluton ages: Papoose Flat $=75-81 \mathrm{Ma}$, Birch Creek $=77-80 \mathrm{Ma}$, Sagehen Flat $=130$ $138 \mathrm{Ma}$, Beer Creek $=150-171 \mathrm{Ma}$, Josuha Flat $=153-184 \mathrm{Ma}$, Santa Rita Flat $=156-160 \mathrm{Ma}$, Paiute Monument $160-190 \mathrm{Ma}$ Marble Canyon-undated (see Sylvester et al. 1978 for details). deformation associated with crystal plasticity is not observed outside the pluton's metamorphic aurole.

As pointed out by Ramsay $(1989$, p. 203), a pluton expanding ("ballooning") as a result of new magma being intruded into the pluton core should be characterised by oblate shape fabrics in the outer (previously solidified) parts of the pluton and adjacent country rocks. The presence of a strong linear element in the grain shape fabric associated with the mylonite in the aureole of the Papoose Flat Pluton is, therefore, difficult to reconcile with a ballooning mechanism of emplacement for the pluton.

It could, of course, be argued that the grain shape lineation in these tectonites is not a true stretching lineation, but has been produced by the superposition of several deformation phases. This alternative explanation may be readily tested through examination of the c-axis pattern of preferred orientation in the quartz-rich tectonites. In crystal-plastic deformation of quartz aggregates, a clear relationship has been documented between strain symmetry and c-axis fabric patterns (see reviews by Schmid \& Casey 1986; Law 1990). While plane strain tectonites are characterised by crossed-girdle fabrics, true oblate strains are associated with small-circle girdles of c-axes centred about the pole of mylonitic foliation (Fig. 3). In this paper, we demonstrate that in all quartz-rich tectonites examined from the Papoose Flat Pluton and its aureole, the grain shape lineation is a true stretching lineation.

Possible supporting evidence for a ballooning emplacement mechanism for the Papoose Flat Pluton was originally thought to be provided by the crystallographic fabrics present within the marble and quartzite of the pluton's metamorphic aureole. The c-axis fabrics originally measured by Sylvester and Christie (1968), and Sylvester (1969) within these plastically deformed and dynamically recrystallised rocks were regarded as being almost symmetrically oriented with respect to foliation and lineation. By analogy with recent experimental and numerical fabric studies (e.g. Tullis et al. 1973; Lister \& Hobbs 1980; Wenk et al. 1987; Jessell 1988) the apparently symmetric cross-girdle quartz and calcite c-axis fabrics described by Sylvester and Christie (1968) and Sylvester (1969) could be interpreted as indicating almost coaxial (i.e. pure shear) deformation histories (Fig. 3). This interpretation would tend to support, at least in general terms, the pluton emplacement model proposed by Sylvester et al. (1978) in which the country rocks deformed coaxially as a passive "blister" on the

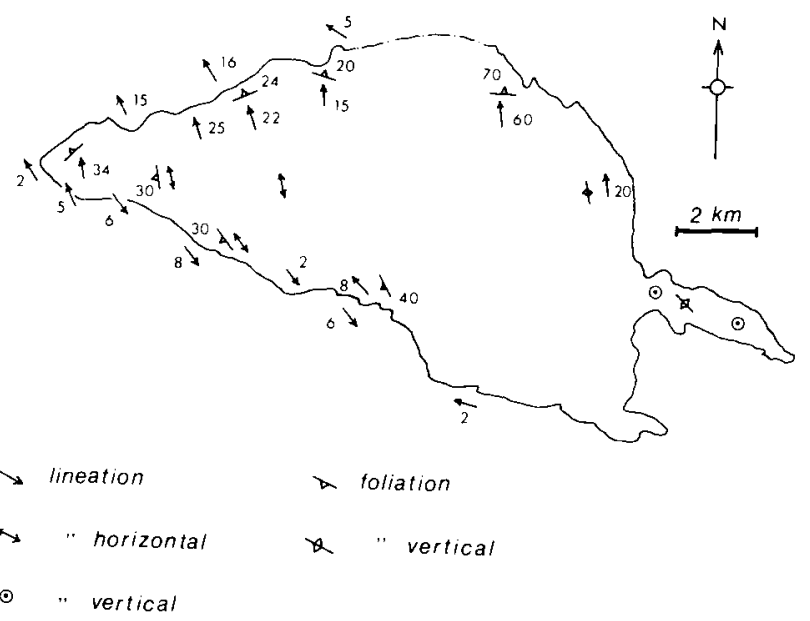

Figure 2 Schematic map of mylonitic foliation and lineation in the Papoose Flat Pluton and its metamorphic aureole; simplified from Neson et al. (1977). 
surface of a sidways-expanding pluton, although deformation is clearly associated with plane strain rather than oblate strains.

The quartz c-axis fabrics described by Sylvester (1966), Sylvester and Christie (1968) and Sylvester (1969) were displayed on projection planes oriented perpendicular to both foliation and lineation. On such projection planes, typical c-axis fabrics (see review by Price 1985) plot around the periphery of the pole figure and are easily misinterpreted. Replotting of the original quartz c-axis fabric data described by Sylvester on projection planes oriented perpendicular to foliation and parallel to lineation has revealed (Law et al. 1990) that the majority of fabrics are in fact assymmetric with respect to foliation and lineation (Fig. 4). By analogy with numerical fabric studies (e.g. Lister \& Hobbs 1980; Etchecopar \& Vasseur 1987) this asymmetrical relationship is considered to be indicative of non-coaxial (approximately simple shear) strain histories (Fig. 3). Further, a consistent sense of fabric asymmetry is detected across the pluton (Fig. 4), suggesting a constant shear sense. Viewed toward the $\mathrm{N}$ and $\mathrm{E}$, a dominantly dextral shear sense is indicated by these fabrics (cf. Figs 3, 4). This top-to-the-SE shear sense has also recently been detected over the pluton by S. R. Paterson and his co-workers (Godin \& Paterson 1991; Paterson et al. 1991a) using microstructures observed within the pluton and its aureole rocks.

As independently outlined by both Law et al. (1990) and Paterson et al. (1991a), therefore, it is possible that pluton evolution and deformation could have involved large-scale, consistently oriented, translation associated with top-to-the-

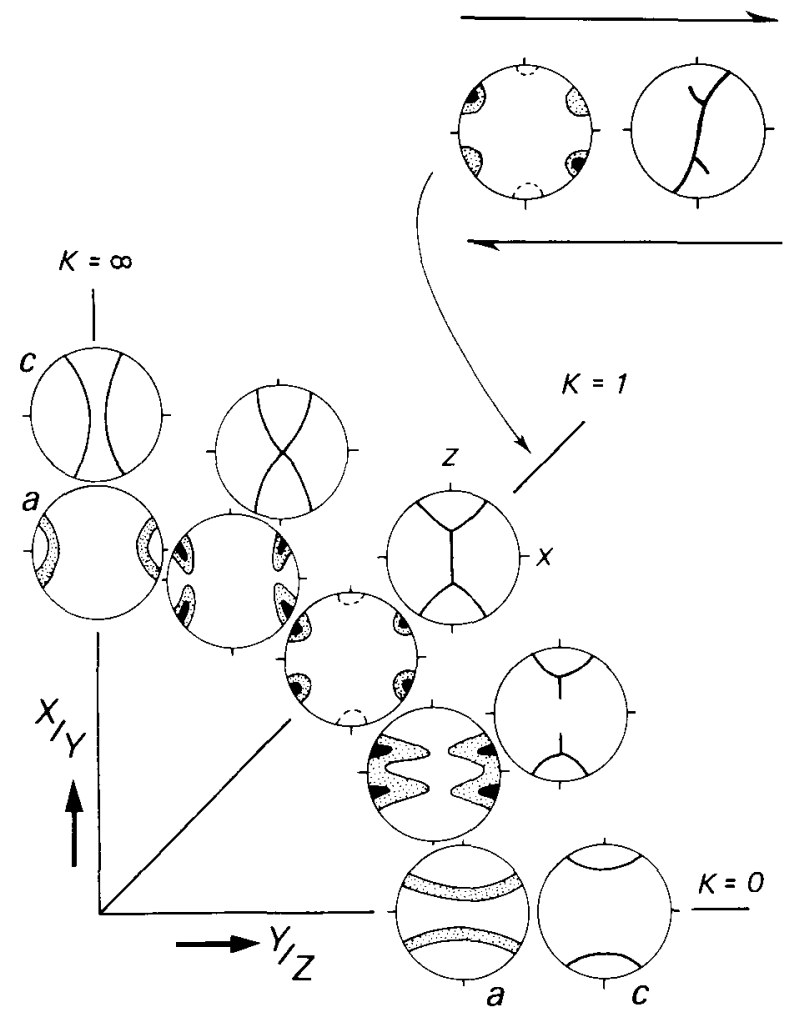

Figure 3 Theoretical relationships (for coaxial deformation) be tween strain symmetry (expressed by Flinn Plot) and quartz c-and a-axis fabrics; oblate strain ellipsoids indicated by $\mathrm{K}=0$, plane strain ellipsoids by $K=1$ and prolate strains by $K=\infty$; quartz c-axis fabrics represented by fabric skeletons; a-axis fabrics represented by contours; lineation $=X$, pole to foliation $=Z$; also shown are $c$ - and a-axis fabrics associated with non-coaxial plane strain (dextral simple shear) deformation; adapted from Schmid \& Casey (1986).
SE shearing rather than passive "blister-like" coaxial deformation associated with an expanding pluton.

In the present paper, a preliminary report is given on the microstructures and crystallographic fabrics contained within a new suite of samples collected from the Papoose Flat Pluton and its aureole. These deformation features are interpreted in the light of recent advances in our understanding of microstructural and crystal fabric evolution (see reviews by Bouchez et al. 1983; Simpson \& Schmid 1983; Lister \& Snoke 1984; Simpson 1986; Law 1990; Hanmer \& Passchier 1991), and their implications for the tectonic history of the area are discussed. Details of the grain-scale microstructural, metamorphic, and crystal fabric deformation features in these tectonites are the subject of on-going research by the authors, and will form the subject of a separate paper.
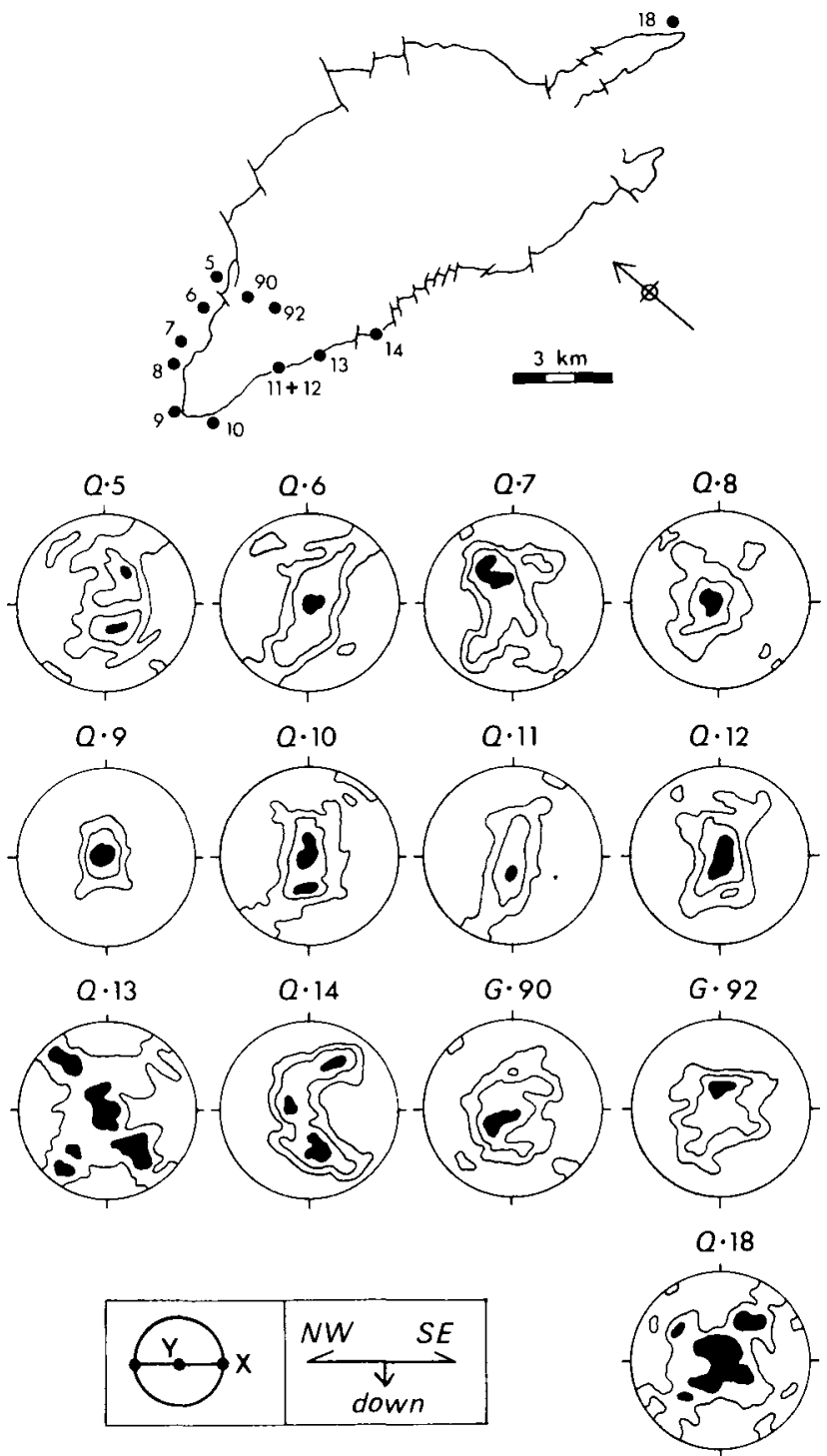

Figure 4 Optically measured quartz c-axis fabrics from the Harkless quartzite $(\mathrm{Q})$ and granitic rocks of the Papoose Flat pluton (G) presented on projection planes parallel to lineation $(X)$ and perpendicular to foliation (XY); these fabrics were originally presented by Sylvester \& Christie (1968, fig. 1) on YZ projection planes and have now been rotated onto the $\mathrm{XZ}$ plane; contour intervals: 1,2 \& 5 times uniform distribution; 300 grains measured in each sample; areas of maximum intensity indicated by solid ornament; location of individual sampling sites indicated; note the dominant sense of fabric asymmetry indicating a top-to-the-SE shear-sense. 


\section{Geological setting}

The Papoose Flat Pluton is one of several granitic bodies situated within the White-Inyo Range of eastern California (Fig. 1) that are regarded as satellites of the Sierra Nevada Batholith (e.g. Bateman et al. 1963; Ross 1965, 1969). The pluton, which is composed mainly of biotite quartz monzonite with $\mathrm{K}$-feldspar megacrysts, crops out as an elongated W-E-trending dome, which is $16 \mathrm{~km}$ long and $8 \mathrm{~km}$ wide (Ross 1967; Nelson et al. 1977; Sylvester et al. 1978). The Papoose Flat Pluton is one of the youngest plutons in the White-Inyo Range, yielding $\mathrm{K}-\mathrm{Ar}$ dates on biotite from two samples of 75 and $81 \mathrm{Ma}$ (Kistler et al.

The White-Inyo Range is an elongate, NNW-trending horst block which is tilted to the $E$ and bounded by high-angle Cainozoic normal and dextral oblique slip faults in Owens Valley to the $W$, and in the Fish Lake, Eureka and Saline valleys to the $E$ (Fig. 1). Most of the range consists of virtually unmetamorphosed late Precambrian and Palaeozoic strata (Nelson 1962; Ross 1965) that are warped into broad folds. Evidence for the Mesozoic structural evolution of the White and Inyo mountains has been summarised by Dunne et al. (1978), who recognised periods of late Permian, middle to late Jurassic, and Cretaceous deformation. In the vicinity of the Papoose Flat Pluton, the dominant structural feature of the Inyo Mountains is the Inyo anticline, a major upright SE-plunging fold (? belonging to the F3 fold phase of Sylvester \& Babcock 1975 ) which is cut by NNW- and NE-striking faults (Nelson 1966).

\subsection{Structure of the pluton}

Detailed accounts of the petrology and structure of the Papoose Flat Pluton have been given by Ross (1965) and Sylvester et al. (1978). Detailed maps, cross-sections and palinspastic reconstructions of the pluton have been presented by Nelson et al. (1977).

The Papoose Flat Pluton has a relatively simple outcrop pattern (Fig. 1) with a long narrow "tail" at its eastern end that Sylvester et al. (1978) refer to as the apophysis. Both the pluton and its aureole are well exposed. Contacts with the country rocks are typically sharp, and dip radially outward at about $30-60^{\circ}$. Around the apophysis, however, the contact is irregular and locally gradational with small screens and inclusions of metamorphosed country rocks (Sylvester et al. 1978).

Sylvester et al. (1978) demonstrated that the pluton is situated structurally within the SW-dipping limb of the Inyo anticline. The pluton is regarded as having cut upward and discordantly across several formations near the core of the fold until it encountered the Poleta Formation, against which the contact is concordant for a distance of $10 \mathrm{~km}$ around the western half of the pluton (Sylvester et al. 1978, fig. 9). Here the Poleta and younger formations were shown by Sylvester et al. (1978) to be deflected to the W and thinned to as little as $10 \%$ of their regional stratigraphic thickness, although in the eastern part of the pluton thinning is not observed where the contact is discordant. Sylvester $e t$ al. (1978) subdivided the granitic rocks into three textural types distinguished by mesoscopic fabric elements: (1) the gneissic border facies, (2) the homogeneous core facies, and (3) the apophysis facies.

The gneissic border facies is most strongly developed within $10-20 \mathrm{~m}$ of the contact around the western half of the pluton, and is characterised by an intensely-developed foliation and lineation. Isolated patches of the border facies are also found where topographically high outcrops are near the inferred position of the pluton's roof. The border facies around the rest of the pluton is also foliated and lineated, although not nearly as strongly as at the western end.

The core facies is a relatively homogeneous quartz monzonite with hypidiomorphic-granular texture, locally containing $\mathrm{K}$-feldspar megacrysts that are invariably euhedral (Sylvester et al. 1978). The apophysis facies is distinguished from the core facies by the elongate habit of about $10 \%$ of the K-feldspar megacrysts. Sub-parallel alignment of these megacrysts imparts a vertical lineation to the granite in the apophysis, possibly indicating magmatic flow; foliation is commonly absent (Sylvester et al. 1978).

\subsection{Structure of the aureole}

Attenuation of the deflected Cambrian strata around the western margin of the Papoose Flat Pluton has been achieved by intense crystal plastic deformation and dynamic recrystallisation of quartz and calcite (Sylvester 1966, 1969; Sylvester \& Christie 1968). This intense plastic deformation has locally resulted in formation of strongly-developed grain shape fabrics (foliation and lineation) and associated crystallographic preferred orientation.

Detailed mapping (Nelson 1966, 1971; Ross 1965, 1967a; Nelson et al. 1977) has revealed that the deflected strata are progressively thinned along the western and southwestern margins of the pluton to less than $10 \%$ of their original stratigraphic thickness (Sylvester et al. 1978). In spite of such extreme attenuation, all major stratal subunits of each formation, which can be recognised in the undeformed, unmetamorphosed sections elsewhere in the White Inyo Range, can also be recognised with confidence in the attenuated section. Such stratigraphic correlations have clearly demonstrated that while stratigraphic continuity is maintained in the attenuated section, strata are not uniformly thinned along strike, but pinch and swell within the aureole (Sylvester 1966; Sylvester et al. 1978).

In contrast to the western part of the Papoose Flat Pluton, intense crystal plastic deformation is rarely observed around the eastern margin of the pluton (i.e. the apophysis). There, discordant contacts at the pluton margin, lack of penetrative deformation features, and hornfels textures in the surrounding country rocks suggest a passive (permitted) rather than forcible emplacement mechanism.

\subsection{Metamorphic petrology of the aureole rocks}

Sylvester (1966) and Sylvester et al. (1978) demonstrated that contact metamorphism of the country rocks surrounding the Papoose Flat Pluton produced a metamorphic aureole of metapelitic and calcareous hornfels and schistose mylonite having mineral assemblages typical of the albite-epidote and hornblende hornfels facies of metamorphism. Two metamorphic zones, which are separated by a gradational contact, were distinguished by Sylvester (1966) and Sylvester et al. (1978): (1) an outer zone, characterised by muscovite- and chlorite-bearing spotted slate and phyllite, reflecting albite-hornfels facies grade of contact metamorphism, and (2) an inner zone, characterised by the presence of biotite and andalusite in pelitic schist and semi-hornfels, reflecting hornblende hornfels grade of contact metamorphism.

The aureole has been mapped by Sylvester (1966, plate 4) as ranging (in plan view) from less than $100 \mathrm{~m}$ to $600 \mathrm{~m}$ in width $\mathrm{N}$ of the pluton, and up to $1,000 \mathrm{~m}$ in width at the eastern end. Inasmuch as the pluton contact dips from $30^{\circ}$ to $45^{\circ}$ away from the pluton, the actual thickness of the aureole 
is of the order of $100-200 \mathrm{~m}$ measured normal to the pluton contact (Sylvester et al. 1978).

\section{Techniques of quartz and calcite petrofabric analysis}

In this paper, all microstructural and crystal fabric data are presented on section planes oriented perpendicular to the mylonitic foliation (XY) and parallel to lineation (X). In all figures, these $\mathrm{XZ}$ section planes are, in a geographical sense, viewed toward the $\mathrm{N}$ and $\mathrm{E}$. Petrofabric analyses have been made of: (1) quartz veins within the gneissic border facies, (2) quartzite and marble within the Poleta Formation located immediately above the gneissic border facies, and (3) quartzite within the overlying Harkless Formation.

Petrofabric analyses of quartz c-axis preferred orientation were carried out on one thin section from each sample collected using an optical microscope and universal stage, a general minimum of $600 \mathrm{c}$-axis being measured in each thin section. The c-axis data are displayed on equal area, upper hemisphere stereographic projections, whose plane of projection contains the sample lineation $(X)$ and pole $(Z)$ to foliation; in all these stereographic projections the foliation is vertical and lineation within the foliation horizontal. The c-axis plots were contoured using the computer program developed by Starkey (1989).

Petrofabric analyses of both calcite and quartz crystallographic preferred orientation in the samples collected were also carried out at ETH, Zurich using an automated Scintag XDS $2000 \mathrm{X}$-ray texture goniometer operating in combined reflection and transmission modes. Quartz c-axes cannot be measured directly with the X-ray texture goniometer, but must be calculated through the Orientation Distribution Function (ODF), from other pole figures obtained by X-ray texture goniometry (Casey 1981). The calculated quartz and calcite c-axis fabrics of representative samples are included in this paper. In representative samples, quartz c-axis fabrics are also compared with their corresponding a-axis fabrics derived from $\mathrm{X}$-ray texture goniometry. Pole figures obtained using $\mathrm{X}$-ray texture goniometry are displayed using the same orientation convention as that previously described for the opticallyderived quartz c-axis fabrics.

\section{Deformation features within the gneissic border facies}

\subsection{Granitic gneiss}

The granitic rocks of the gneissic border facies are characterised by an intensely-developed foliation. This foliation, which is defined by parallelism of mica flakes and plastically deformed quartz aggregates, anastomoses around the large $(0.5-2.0 \mathrm{~cm})$ euhedral-rounded K-feldspar megacrysts present within the gneiss. The foliation is parallel to both the pluton-country rock contact and to lithologic layering and tectonic foliation in the locally surrounding country rock strata. The main lineation in the granitic rocks is defined by a shape preferred orientation of elongate mica blebs and quartz aggregates. In general, the lineation trends NW-SE and plunges gently. All features so far observed within the gneissic border facies are indicative of solid state deformation. No unequivocal evidence for a magmatic foliation (see review by Paterson et al. 1989) has been observed within these rocks either during the present study or by previous workers (Sylvester et al. 1978; Paterson et al. 1991a).

Few unequivocal macroscopic shear sense indicators have been observed to date within the gneissic border facies in our study (cf. Paterson et al. 1991a, p. 325). In joint faces oriented perpendicular to foliation (XY) and parallel to lineation $(\mathrm{X})$, the gneiss appears to be characterised by a symmetric relationship between feldspar megacrysts, anastomosing foliation, and pressure-shadow development (Fig. 5(a)). Such an apparent lack of unequivocal shear sense indicators within these L-S tectonites suggests an approximately coaxial bulk deformation history (Morgan et al. 1991).

\subsection{Quartz veins in the gneissic border facies}

The granitic rocks of the gneissic border facies are cut by a series of thin $(10-50 \mathrm{~cm})$ aplitic sills and dykes which, at least locally, are intensely folded. An axial planar foliation defined by the preferred alignment of feldspar and quartz grains is present in the folded aplites. This axial planar foliation is oriented parallel to foliation in the surrounding gneiss. Both the aplites and the granitic rocks of the gneissic
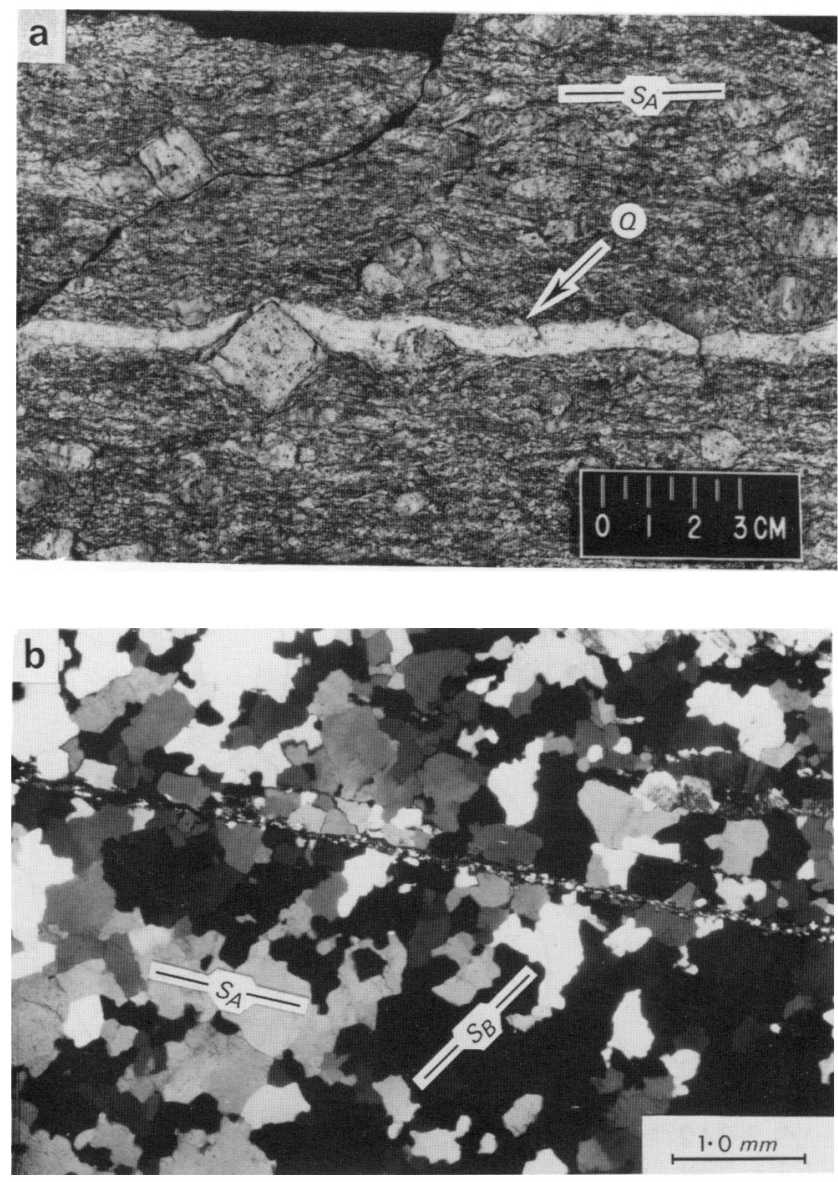

Figure 5 Mylonitic rocks from the gneissic border facies.

(a) Joint face displaying typical macroscopic fabric elements in a hand sample (not in situ) from the gneissic border facies (sample PF.38); joint face is oriented parallel to stretching lineation and perpendicular to mylonitic foliation; note lack of any obvious shear-sense indicators at the hand sample scale; $\mathrm{Q}=$ Mylonitic quartz vein.

(b) Photomicrograph (viewed toward the NE) of a mylonitic quartz vein (sample PF.1) within the pluton's gneissic border facies; elongate dynamically recrystallised quartz grains display a preferred alignment $\left(S_{B}\right)$ which is oblique to mylonitic foliation $\left(S_{A}\right)$; sense of obliquity suggests a dextral (top-to-the-SE) shear sense; angle of obliquity is greater than $45^{\circ}$; scale bar $=1 \mathrm{~mm}$ (1000 microns). 
border facies are cut by a series of thin $(10-30 \mathrm{~cm})$ quartz veins, which are commonly oriented parallel to the foliation in the surrounding gneiss. The quartz veins are also intensely foliated and lineated, the foliation and lineation being generally oriented parallel to foliation and lineation in the immediately surrounding gneiss.
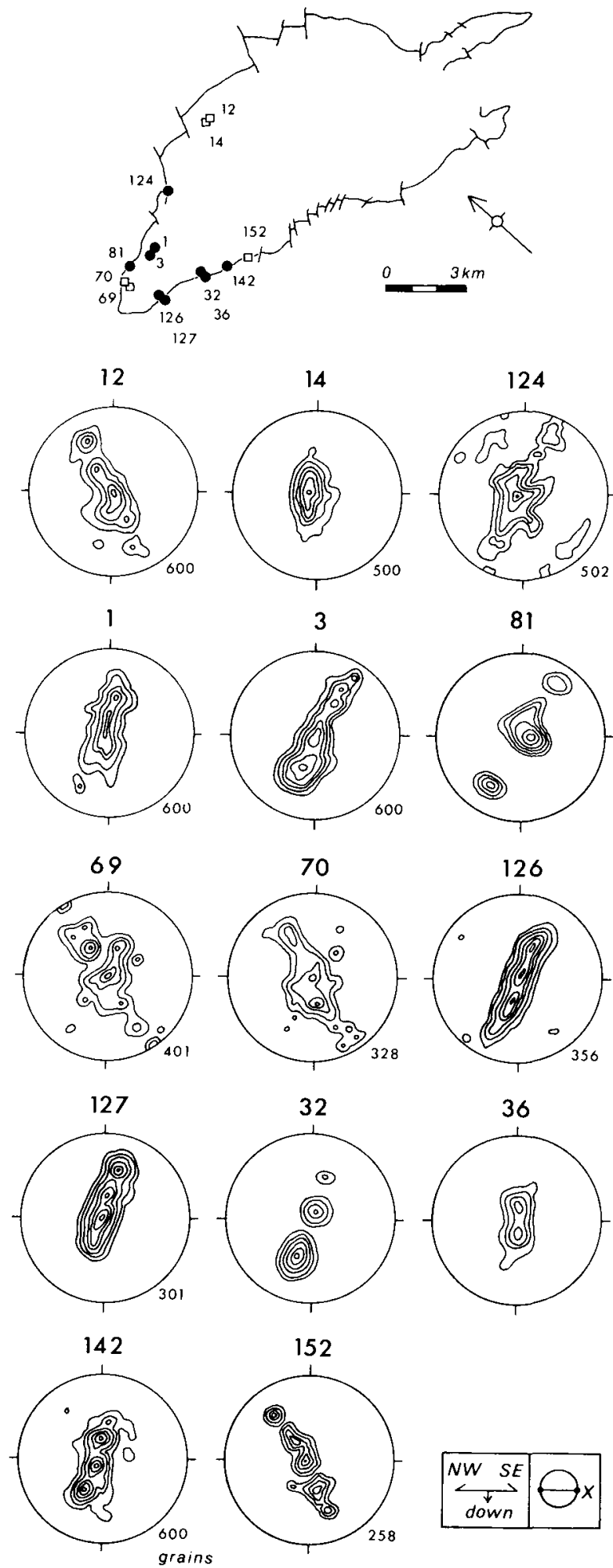

Figure $6 \mathrm{C}$-axis fabrics (viewed towards the NE) from selected mylonitic quartz veins within the gneissic border facies; fabrics in samples PF.32, 36 and 81 measured by X-ray texture goniometry and ODF analysis, all other fabric measured optically; locations of samples indicating dextral (top-to-the-SE) shear-sense indicated by circles; location of samples indicating sinistral shear sense indicated by squares; contour intervals: $1,2,3,5,10,15$ and 20 times uniform distribution.
In $\mathrm{XZ}$ thin sections, the quartz veins are composed of equant to elongate recrystallised grains ranging in size from $400-1,000 \mu \mathrm{m}$. The elongate quartz grains are commonly aligned with their long axes oblique to the macroscopic foliation (Fig. 5b). Adopting the nomenclature introduced by Law et al. (1984), this preferred alignment of elongate recrystallised grains is referred to as $S_{B}$. The sense of obliquity between $S_{B}$ and mylonitic foliation $\left(S_{A}\right)$ may be used as a shear sense indicator (see reviews by Bouchez et al. 1983; Simpson \& Schmid 1983). In the majority of veins examined, the sense of obliquity between $S_{A}$ and $S_{B}$ indicates a top-to-the-SE shear sense (e.g. Fig. 5b). Local exceptions to this general observation are described in Section 4 of this paper.

Internally, the grains display either straight or slightly undulatory extinction. Subgrains are rarely observed in the optical microscope. Grain boundaries are commonly lobate, suggesting the importance of grain boundary migration. Taken together, these microstructural features clearly indicate the importance of dynamic recrystallisation at relatively high homologous temperatures within the quartz veins (see reviews by Urai et al. 1986; Knipe \& Law 1987).

All quartz veins within the gneissic border facies are characterised by intensely-developed asymmetric single girdle c-axis fabrics (Fig. 6). In ten of the fourteen quartz vein samples so far analysed by optical and $\mathrm{X}$-ray texture goniometry methods, a top-to-the-SE shear sense is indicated by obliquity between the c-axis single girdle and foliation and lineation (cf. Figs 3, 4, 6). For all individual quartz veins examined, the same shear sense is indicated by both crystal fabric asymmetry and obliquity between $S_{A}$ and $\mathrm{S}_{\mathrm{B}}$.

In Figure 7 , the optically-measured c-axis fabric from sample PF.1, collected from a quartz vein located on the NW margin of the pluton (Fig. 6), is compared with the sample's corresponding a-axis pole figure measured by $\mathrm{X}$-ray texture goniometry. This a-axis fabric is representative of all quartz veins analysed in the present study. The a-axis fabric is composed of three point maxima aligned within the $\mathrm{XZ}$ plane and, by analogy with quartz fabric modelling studies (Fig. 3), clearly indicates that the quartz veins have undergone plane strain deformation, and that the grain shape lineation is a true stretching lineation.

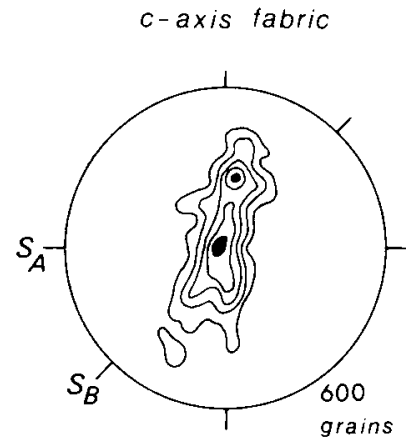

$$
\begin{aligned}
& \text { Maximum intensity } \\
& 34 \text { times uniform }
\end{aligned}
$$

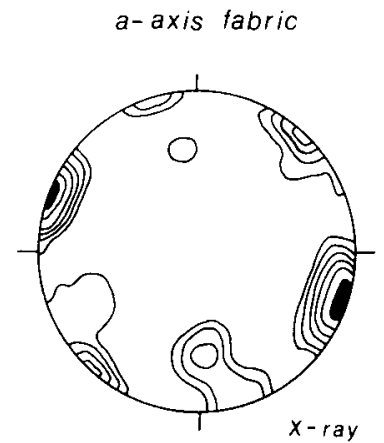

Maximum intensity

19 times uniform
Figure 7 Comparison of optically measured c-axis fabric from a mylonitic quartz vein (sample PF.1) and the corresponding a-axis fabric measured by X-ray texture goniometry; the a-axis fabric consists of three strong point maxima positioned close to the $\mathrm{XZ}$ plane (cf. Fig. 3); contour intervals: 1, 2, 5, 10 and 20 times uniform distribution (c-axis fabric); 1, 2, 3, 5, 7, 9 and 11 times uniform distribution (a-axis fabric). 


\section{Plastically deformed rocks of the metamorphic aureole}

Five detailed sampling traverse have been made around the western margin of the Papoose Flat Pluton outward from the gneissic border facies into the penetratively deformed metasedimentary rocks of the aureole (Fig. 8). In all of these measured sections, microstructural analysis indicates that both quartzite and marble in the Poleta, Harkless and Saline Valley formations have suffered intense crystal plastic deformation (Sylvester \& Christie 1968; Sylvester 1969). This intense deformation caused formation of a strong mylonitic foliation oriented parallel to both lithologic layering and the pluton margin, and a mineral stretching lineation that is particularly well developed in the quartzite.

In the following sections, each sampling traverse is described in turn with particular emphasis on the observed microstructural and crystal fabric shear sense indicators. Cross-sections illustrating these traverses are all drawn parallel to the local dip direction of mylonitic foliation and lithologic layering.

\subsection{Traverse $A$}

The complete stratigraphic sequence of the Poleta Formation is exposed in this measured section (Fig. 9). Here the Poleta Formation has been tectonically thinned to $10 \%$ of its regional stratigraphic thickness (Sylvester et al. 1978). This extreme tectonic thinning is expressed in outcrop by an intensely-developed mylonitic foliation in the Poleta and Harkless formations, as well as the underlying gneissic border facies. Within the mylonitic foliation, a mineral elongation lineation is strongly developed in both quartz-rich units of the Poleta and Harkless formations, and in mylonitic quartz veins in the underlying gneissic border facies. This mineral lineation plunges gently to the SE approximately perpendicular to the cross-section in Figure 9.

Both the mylonitic quartzite within the Harkless and Poleta formations, and the mylonitic quartz veins (PF.32 \&

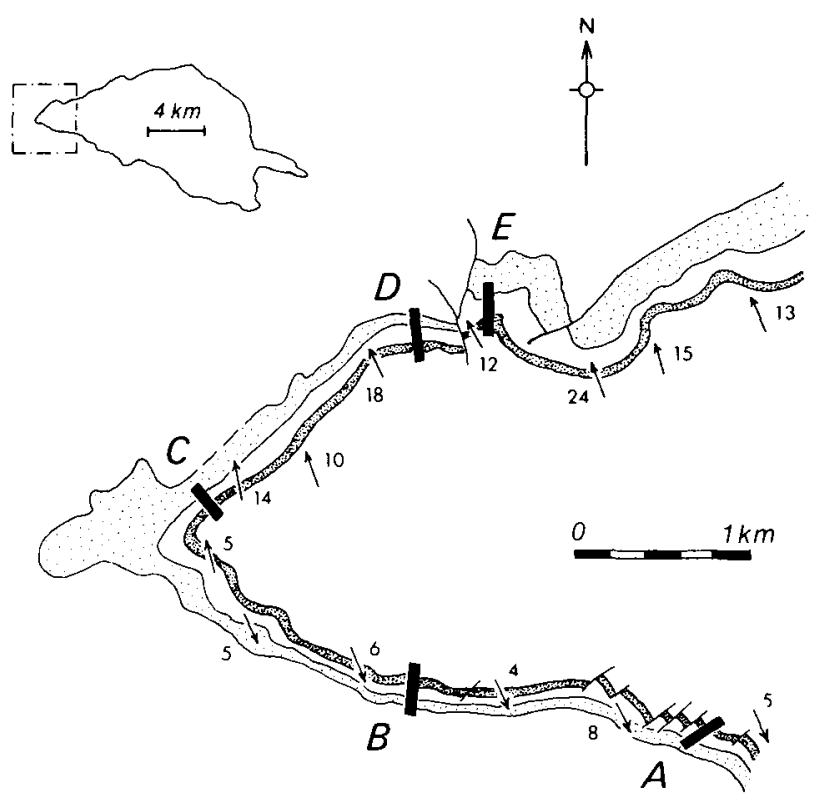

Figure 8 Locations of the five sampling traverses (A-E): all traverses are oriented parallel to the local dip direction of mylonitic foliation; local trend and plunge of lineation indicated by arrows; Poleta Formation $=$ dense stipple pattern, Harkless Formation = unornamented, Saline Valley formation = light stipple.
36) in the gneissic border facies, display intensely developed c-axis fabrics (Fig. 9). While the mylonitic aureole rocks are characterised by cross-girdle c-axis fabrics, the mylonitic quartz veins are characterised by single girdle fabrics. All quartz c-axis fabrics are asymmetric with respect to foliation and lineation in terms of either skeletal outline or density distribution. The sense of asymmetry indicates a dextral (top-to-the-SE) shear-sense. This inferred shear-sense is confirmed by the microstructures in the Poleta and Harkless quartzite and schist (Fig. 10(a)-(d)). Shear bands (extensional crenulation cleavage) are well developed in the pelitic layers of both the Harkless and Poleta formations. These shear bands intersect the penetrative foliation in a line oriented perpendicular to the stretching lineation and consistently indicate a top-to-the SE shear-sense.
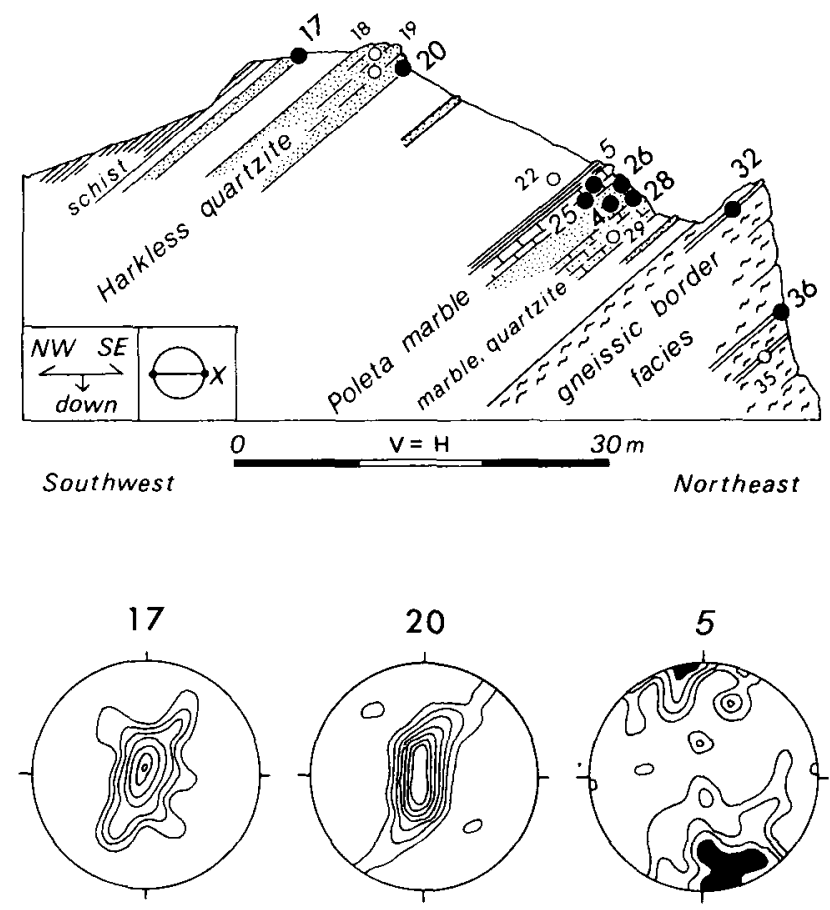

25

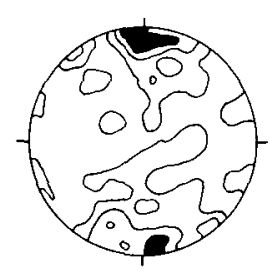

28
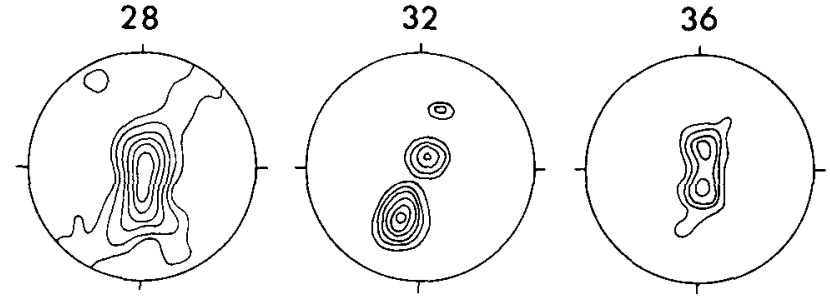

Figure 9 Cross-section along Traverse A: location of sampling sites indicated; PF.5 and 25: calcite c-axis fabrics; all other samples: quartz c-axis fabrics; with the exception of sample PF.4, all c-axis fabrics measured by $\mathrm{X}$-ray texture goniometry and ODF analysis; 1500 quartz grains measured optically in PF.4; note: mineral stretching lineation along this traverse is sub-perpendicular to the measured cross-section; contour intervals: $1,3,5,7,9,11,13$ and 15 times uniform distribution (quartz fabrics), 1, 2, 3 and 4 times uniform (calcite fabrics), areas of maximum intensity indicated by solid ornament. 
All the c-axis fabrics measured by X-ray texture goniometry are characterised by an intense point maximum (up to ten times uniform distribution in the quartzite, up to 25 times uniform in the quartz veins) oriented within the foliation perpendicular to lineation. In geological terranes where crystal fabric evolution is associated with regional metamorphism, such $\mathrm{Y}$ axis point maxima fabrics, which are inferred to indicate the dominance of prism slip, are almost always associated with either amphibolite facies or higher conditions of metamorphism (see reviews by Schmid \& Casey 1986; Law 1990).

Strong calcite crystallographic fabrics are also present in this section (Fig. 9). The Poleta marble (samples PF.5 and 25 ) is characterised by a calcite c-axis point maximum oriented within the $\mathrm{XZ}$ specimen plane at a low angle to the foliation pole (Z). Calcite-dolomite geothermometry of sample PF.5 indicates minimum temperatures of metamorphism of $530-540^{\circ} \mathrm{C}$ and $480-490^{\circ} \mathrm{C}$ using the models of Rice (1977) and Annovitz and Essene (1987), respectively. Shear-sense interpretation of calcite fabric asymmetry is, due to the possibility of twinning, more complicated than in the case of quartz (see reviews by Schmid et al. 1987; Law 1990). The sense of asymmetry in the calcite c-axis fabrics from samples PF.5 and 25 is indicative of sinistral (top-to-the-NW) shear, assuming the fabrics are produced by dislocation creep rather than later twinning deformation.

Quartz a-axis fabrics for Traverse $A$ are shown in Figure 11. With the exception of sample PF.29, all quartzites and quartz veins measured in this section are characterised by three a-axis point maxima oriented within the $\mathrm{XZ}$ plane. These fabrics indicate plane strain deformation conditions (cf. Figs 3, 11). In contrast, the a-axis fabric for sample PF.29 (situated $3.6 \mathrm{~m}$ above the pluton margin) consists of a broad small-circle girdle of a-axes centred about the pole $(Z)$ to mylonitic foliation. Such small-circle girdle a-axis fabrics indicate deformation in the flattening field (Fig. 3). This strain symmetry interpretation agrees with the observation that, particularly around the NW margin of the pluton, the lowermost pelitic units of the Poleta Formation, although lineated, also contain foliation-parallel garnet-rich skarn deposits with chocolate-tablet boudinage structures (Sylvester \& Christie 1968, plate 1).

\subsection{Traverse B}

In this measured section (Fig. 12) the Poleta Formation is even more intensely thinned than in Traverse $A$. The c-axis
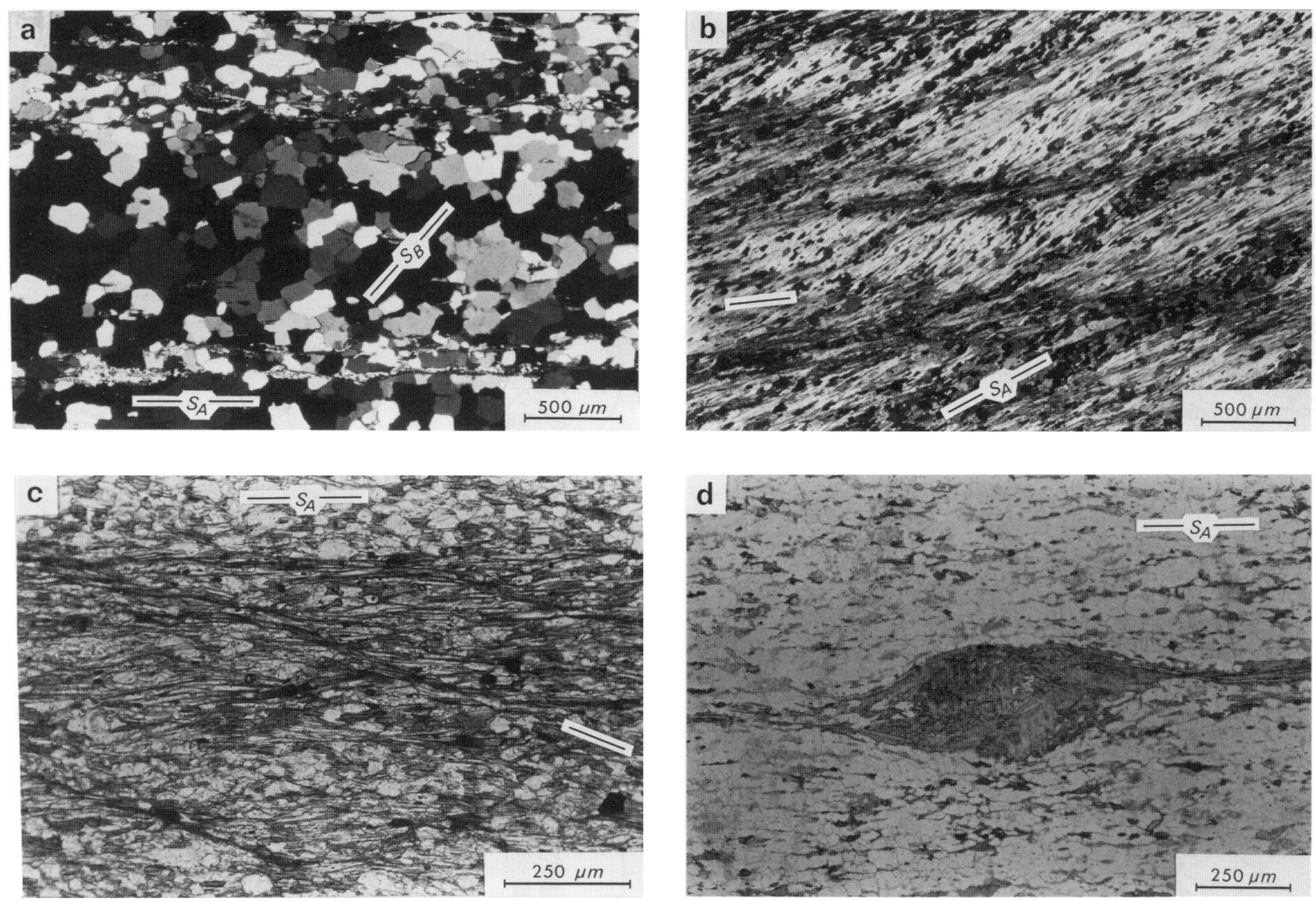

Figure 10 Photomicrographs (viewed toward the NE) of schist and mylonitic quartzite from the Harkless Formation exposed in Traverse $\mathrm{A}$; in all cases a dextral (top-to-the-SE) shear sense is indicated by the observed microstructures.

(a) Preferred alignment $\left(S_{B}\right)$ of elongate, dynamically recrystallised quartz grains which dip more steeply to the NW than mylonitic foliation $\left(S_{A}\right)$ defined by phyllosilicates (sample PF.18); cross-polarised light.

(b) Shear bands (extensional crenulation cleavage) within Harkless black schist (sample PF.22); foliation $\left(\mathrm{S}_{\mathrm{A}}\right)$ defined by phyllosilicates; orientation of shear bands indicated by bar; cross-polarised light.

(c) Shear band (extensional crenulation cleavage) within thin micaceous quartzite layer from the Poleta Formation (sample PF.26); foliation $\left(\mathrm{S}_{\mathrm{A}}\right)$ defined by phyllosilicates and elongate quartz grains; orientation of shear bands indicated by bar; plane-polarised light.

(d) Asymmetric overgrowths on phyllosilicate clast within thin micaceous quartzite layer from the Poleta Formation (sample PF.29); overgrowths are parallel to mylonitic foliation $\left(S_{\mathrm{A}}\right)$; plane-polarised light. 
preferred orientation of three mylonitic quartzite samples from the Harkless Formation, and two mylonitic quartz veins from the underlying gneissic border facies, have been optically measured in this section. All are asymmetric fabrics. A top-to-the-SE shear sense is indicated within both the mylonitic quartz veins (PF126 and 127) and the quartzite samples. This shear sense is also indicated by shear bands (extensional crenulation cleavage) in the overlying Harkless schist.

\subsection{Traverse $C$}

A domainal distribution of quartz c-axis fabric asymmetry has been detected in the Harkless quartzite of this section (Fig. 13). At a structural distance of $23.2 \mathrm{~m}$ above the pluton contact (sample PF.90), fabric asymmetry indicates a sinistral (top-to-the-NW) shear sense. In contrast, at $25.3 \mathrm{~m}$ above the contact, the measured $\mathbf{c}$-axis fabric from sample PF.89 is almost symmetric with respect to foliation and lineation, indicating approximately coaxial (pure shear) deformation. At $39.6 \mathrm{~m}$ above the contact, the c-axis fabric (PF.88), although symmetric in terms of skeletal outline, is asymmetric in terms of density distribution. This density asymmetry may indicate a weak component of dextral (top-to-the-SE) shear. No clearly unambiguous microstr-

17
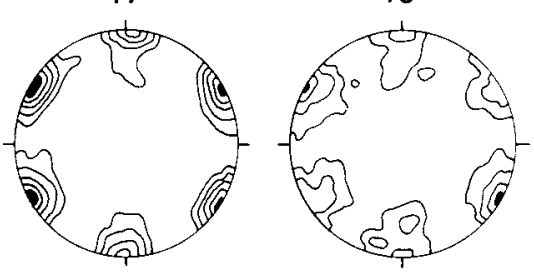

21

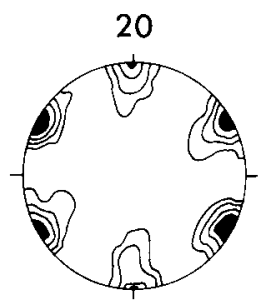

4

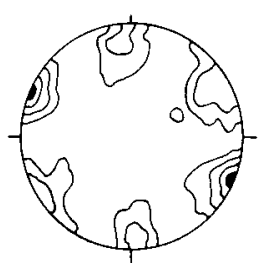

32
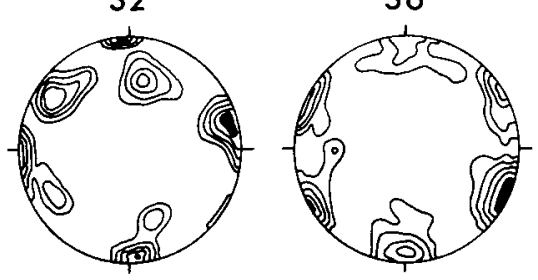

28
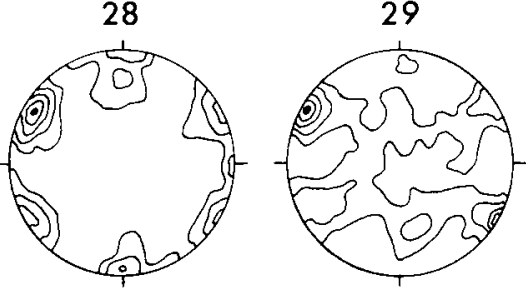

35

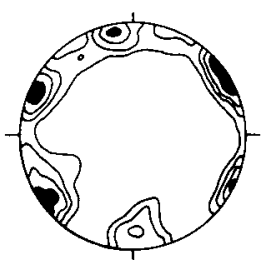

Figure 11 Quartz a-axis fabrics from Traverse A viewed toward the NE; see Figure 9 for sample localities and orientation convention; all fabrics measured by $X$-ray texture goniometry; only sample PF.29 displays a small circle girdle distribution of a-axes centred about the pole $(Z)$ to mylonitic foliation; contour intervals: $1,2,4,6$ and 7 times uniform; areas of maximum intensity indicated by solid ornament. uctural shear sense indicators have been observed within either the Harkless quartzite or schist exposed along this section.

All three c-axis fabrics are characterised by an intense $Y$ point maximum with c-axis intensity values ranging between ten and twelve times uniform distribution. As discussed in Section 4.1 , these point maxima indicate relatively high temperatures of deformation.

The Poleta marble (sample PF.93) in this section also displays a strong crystallographic preferred orientation (Fig. 13). The calcite c-axis fabric is asymmetric with respect to foliation and lineation and consists of two intense point maxima, the dominant point maximum (ten times uniform distribution) being oriented within the $\mathrm{XZ}$ plane at a low angle to the pole to foliation (Z). Calcite-dolomite geothermometry of sample PF.93 indicates minimum temperatures of metamorphism of $420-500^{\circ} \mathrm{C}$ and 380 $460^{\circ} \mathrm{C}$ using the models of Rice (1977) and Annovitz and Essene (1987), respectively. The sense of asymmetry in the calcite c-axis fabric from sample PF.93 indicates dextral (top-to-the-SE) shear assuming the fabric is produced by dislocation creep rather than later twinning deformation.

\subsection{Traverse D}

A domainal distribution of shear sense regimes has also been revealed by microstructural and crystal fabric analysis
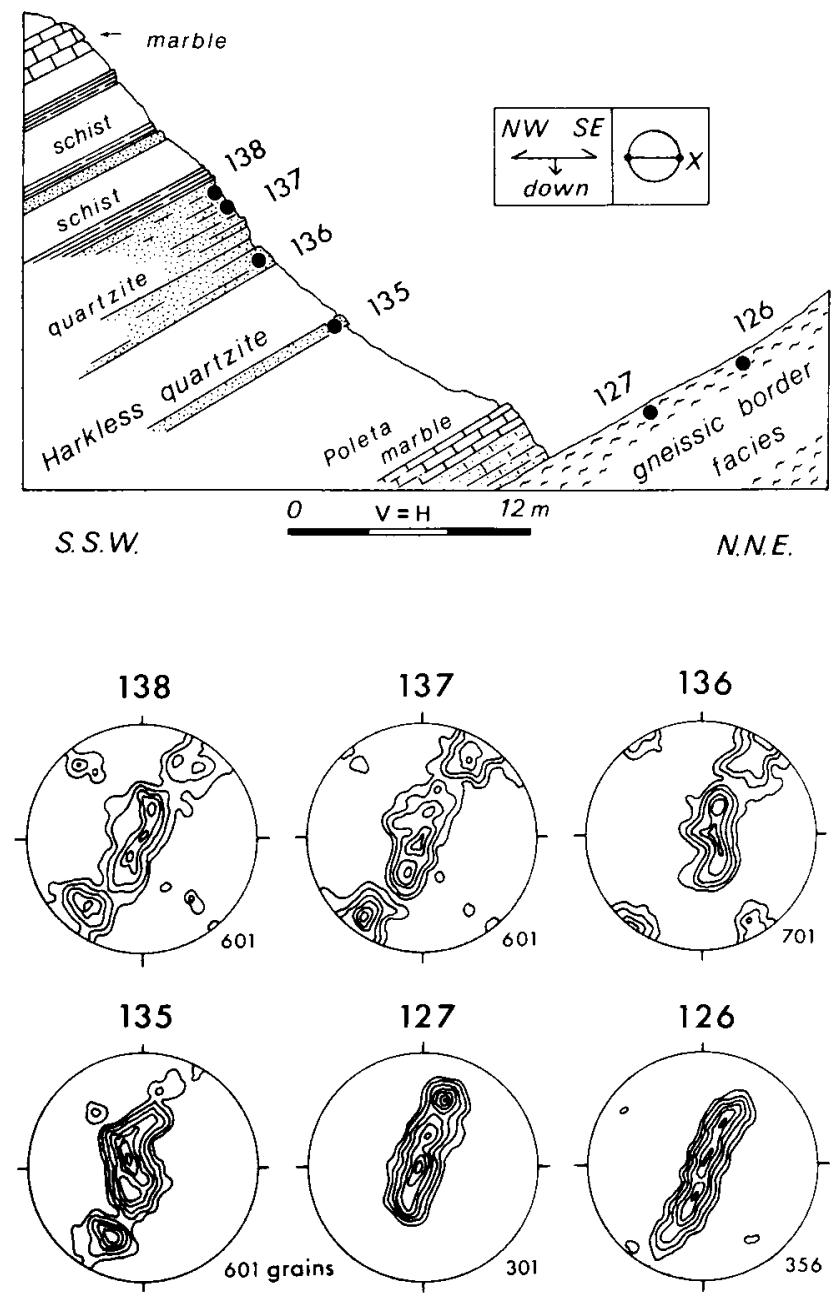

Figure 12 Cross-section along Traverse $B$; location of sampling sites indicated; all fabrics are optically measured quartz $\mathbf{c}$-axis fabrics; contour intervals: $1,2,4,6,10,15$ and 20 times uniform; note: mineral stretching lineation along this traverse is subperpendicular to the measured cross-section. 
of samples collected along Traverse D (Fig. 14). A top-to-the-NW shear-sense is indicated by asymmetric c-axis fabrics in two quartz veins (samples PF.69 and PF.70) in the gneissic border facies at distances of 0.5 and $3.5 \mathrm{~m}$ beneath the pluton's margin. This shear sense is confirmed by the preferred alignment $\left(S_{B}\right)$ of elongate recrystallised quartz grains oriented oblique to mylonitic foliation $\left(S_{A}\right)$. Similarly, in the surrounding gneiss a weak component of top-to-theNW shear is indicated by rare asymmetric fibrous overgrowths on feldspar porphyroclasts. In contrast, within the Harkless quartzite above the pluton margin, a top-to-the-SE shear-sense is indicated by asymmetric quartz c-axis fabrics. Macroscopic shear bands (extensional crenulation cleavage) within the overlying Harkless schist also clearly indicate a top-to-the-SE shear-sense. All c-axis quartz fabrics are characterised by $\mathrm{Y}$-axis point maxima indicating relatively high temperatures of deformation.

In this section, calcite-dolomite geothermometry has been carried out on two samples of Poleta marble. For sample PF.71 (collected $0.5 \mathrm{~m}$ above the pluton margin), minimum temperatures of metamorphism of $510-530^{\circ} \mathrm{C}$ and 470 $490^{\circ} \mathrm{C}$ are indicated using the models of Rice (1977) and Annovitz and Essene (1987), respectively. Similarly, at a structurally higher level (11.6 $\mathrm{m}$ above the pluton margin),
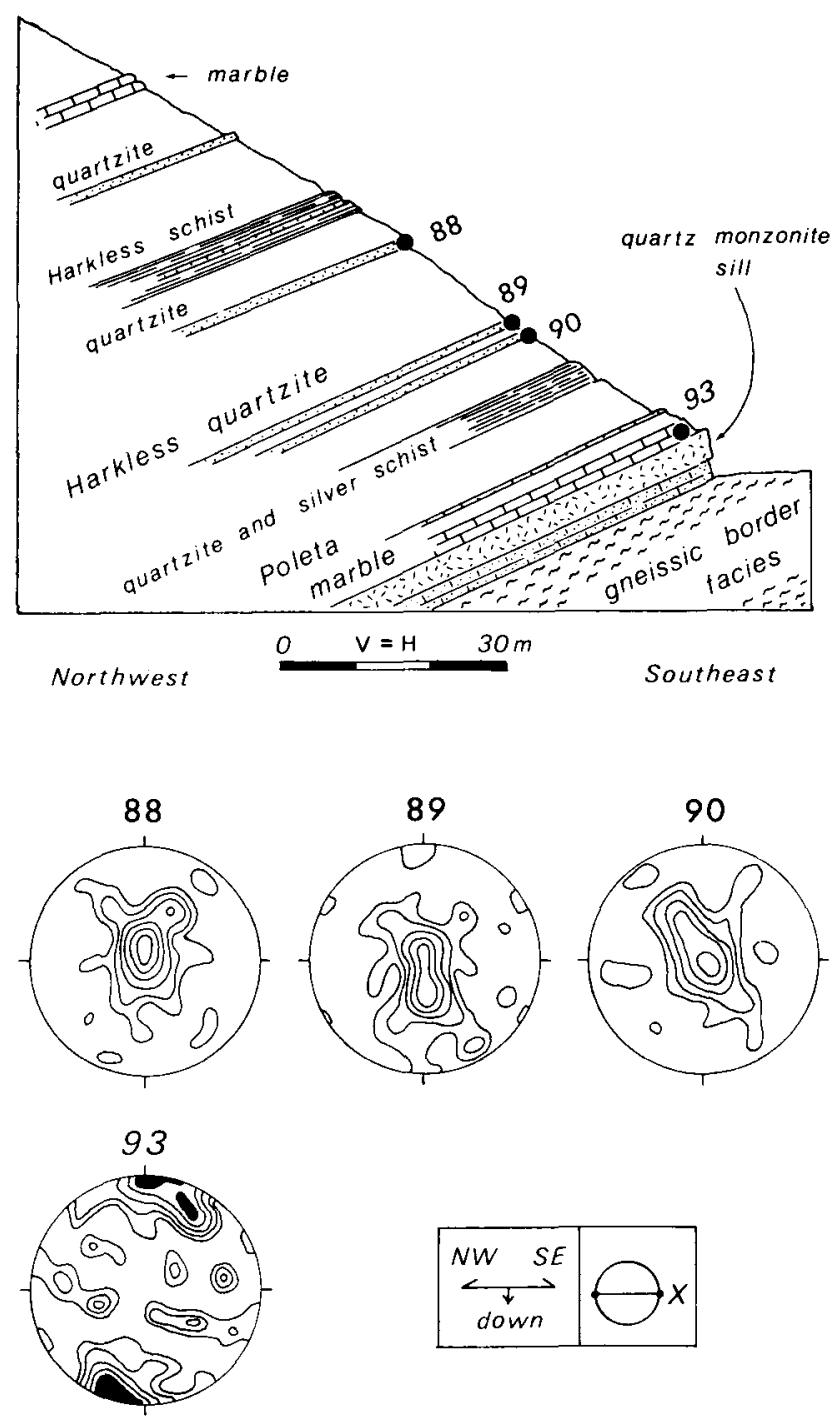

Figure 13 Cross-section along Traverse C; location of sampling sites indicated; sample PF.93: calcite c-axis fabric; all other samples: quartz c-axis fabrics; all fabrics measured by $\mathrm{X}$-ray texture goniometry and ODF analysis; contour intervals: 1, 2, 3, 4, 5, 6 and 7 times uniform distribution. minimum temperatures of metamorphism of $490-530^{\circ} \mathrm{C}$ and $450-490^{\circ} \mathrm{C}$ are estimated for sample PF. 72 .

Sample PF.71 is characterised by a calcite c-axis fabric which is markedly asymmetric with respect to foliation and lineation (Fig. 14). The sense of asymmetry in this fabric is indicative of dextral (top-to-the-SE) shear if the fabric was produced by dislocation creep rather than later twinning deformation.

\subsection{Traverse $E$}

Traverse $\mathrm{E}$, on the northern margin of the pluton, extends in a $\mathrm{S}-\mathrm{N}$ direction from the gneissic border facies, upward through the Poleta and Harkless formations into the marble of the Saline Valley Formation (Fig. 15). The stretching lineation in this series of outcrops plunges NW, sub-parallel to the plane of cross-section.

Calc-silicate skarn deposits are well developed in the schist of the Poleta formation located immediately above the pluton. These foliation-parallel, layered skarn deposits clearly display three-dimensional pinch and swell structures (chocolate-tablet boudinage), the more rigid garnet and epidote-rich skarn layers being segmented into a series of oblate spheroids around which the schistose layering in the pelitic schist anastomoses (Sylvester \& Christie 1968, plate 1 ). The grain shape lineation lying within the foliation in
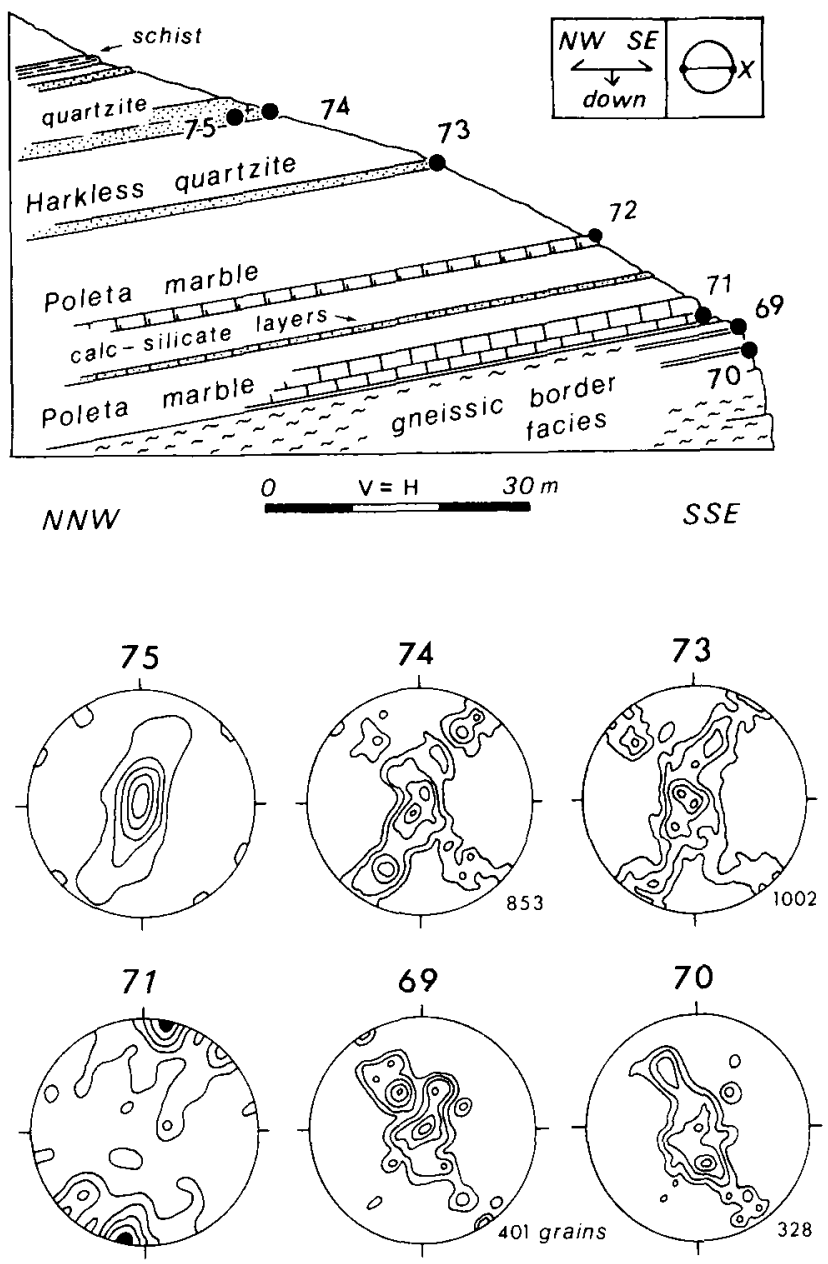

Figure 14 Cross-section along Traverse D; location of sampling sites indicated; sample PF.71: calcite c-axis fabric; all other samples: quartz c-axis fabrics; samples PF.75 and 71 measured by X-ray texture goniometry and ODF analysis; all other fabrics measured optically (number of grains measured in each sample is indicated); contour intervals: $1.0,1.5,2.0,2.5$ and 3.0 times uniform distribution (calcite fabric-PF.71); 1, 2, 3, 5, 7 and 9 times uniform (all quartz fabrics). 
these schists trends parallel to the stretching lineation in both the underlying gneissic border facies and the overlying mylonitic marble and quartzite.

An intense c-axis preferred orientation is detected in sample PF.81 collected from a mylonitic quartz vein $3.0 \mathrm{~m}$ beneath the pluton-cover rock contact within the gneissic border facies. The c-axis fabric consists of three point maxima aligned on a single girdle whose asymmetry with respect to foliation and lineation indicates a top-to-the-SE shear-sense (Fig. 15). The same shear sense is indicated by the asymmetric cross-girdle c-axis fabric measured within sample PF.77 collected from the Harkless quartzite at a measured distance of $26.0 \mathrm{~m}$ above the pluton's margin.

Asymmetric calcite crystal fabrics have also been detected in the marble layers exposed along this traverse. Sample PF.80, collected within the Poleta Formation at a distance of $11.0 \mathrm{~m}$ above the pluton's margin, exhibits a calcite c-axis fabric (Fig. 15) whose sense of asymmetry is consistent with a top-to-the-SE shear-sense, assuming that intracrystalline deformation is associated with dislocation processes rather than twinning (see review by Law 1990).

Within marble of the structurally higher Saline Valley Formation, a top-to-the-SE shear-sense is indicated by elongate, dynamically recrystallised calcite grains that dip more steeply to the NNW than the main mylonitic foliation. In thin section, these oblique grain shapes defining $S_{B}$ are extremely elongate (aspect ratios of between $3: 1$ and $5: 1$ ) and are interpreted as being produced by dynamic recrystallisation and associated dislocation processes rather than by twinning. In some layers, this oblique grain shape alignment is visible at the hand sample scale (Fig. 16). The main mylonitic foliation $\left(\mathrm{S}_{\mathrm{A}}\right)$ and the oblique grain shape alignment $\left(S_{B}\right)$ intersect in a line that is oriented perpendicular to the mineral stretching lineation.
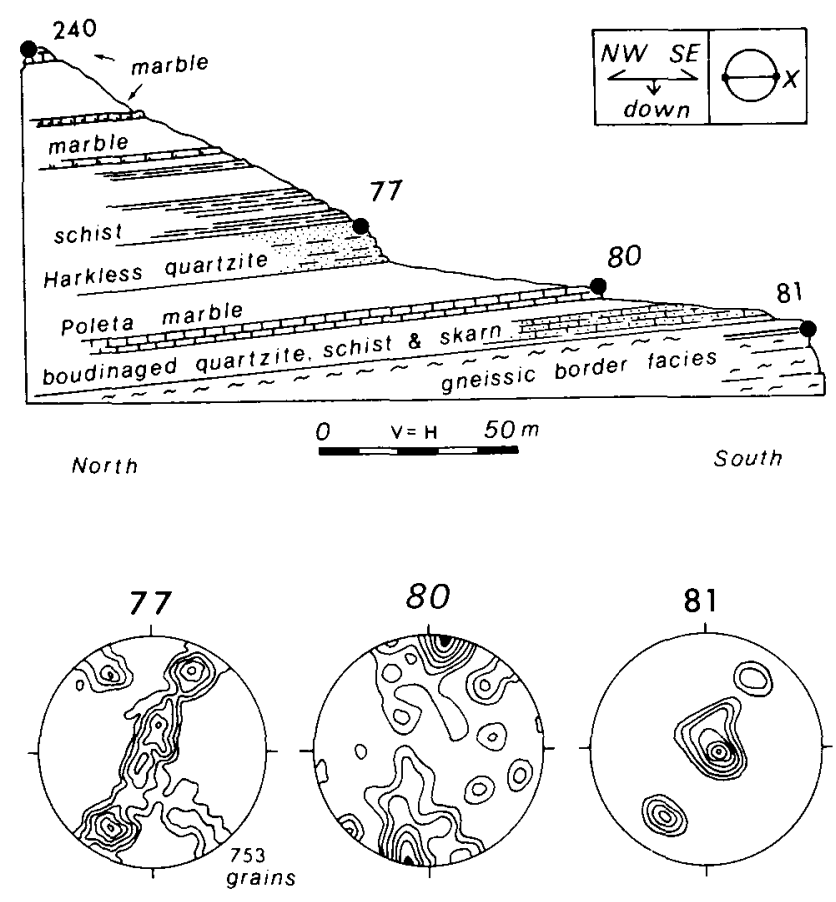

Figure 15 Cross-section along Traverse $\mathrm{E}$; location of sampling sites indicated; sample PF.80: calcite c-axis fabric; PF.77 and 81; quartz c-axis fabrics; PF.77 measured optically, samples PF.80 and 81 measured by X-ray texture goniometry and ODF analysis; contour intervals: $1,2,3,4,5,6$, and 7 times uniform distribution (PF.77 and 80); 4, 5, 6, 7, 10 and 13 times uniform (PF.81).

\section{Discussion}

\subsection{Strain path and temperature of deformation}

Both microstructural and crystal fabric analysis of the mylonitic cover rocks situated in the contact aureole surrounding the western part of the Papoose Flat Pluton indicate that deformation was dominated by strongly non-coaxial, plane strain conditions. Within the underlying pluton's gneissic border facies, similar strain path conditions are indicated by microstructures and crystal fabrics in the mylonitic quartz veins. In contrast, the apparent rarity of unequivocal shear sense indicators in the gneiss would appear to indicate a more coaxial strain path. Only locally within calc-silicate rocks located immediately above the pluton margin have we observed both shape fabrics and crystallographic fabrics indicative of deformation within the flattening field.

The microstructural and crystal fabric kinematic indicators reported in this study clearly indicate a dominant top-to-the-SE shear sense associated with crystal plastic deformation. Exceptions to this general observation are present, but appear to be restricted to fairly localised structural domains.

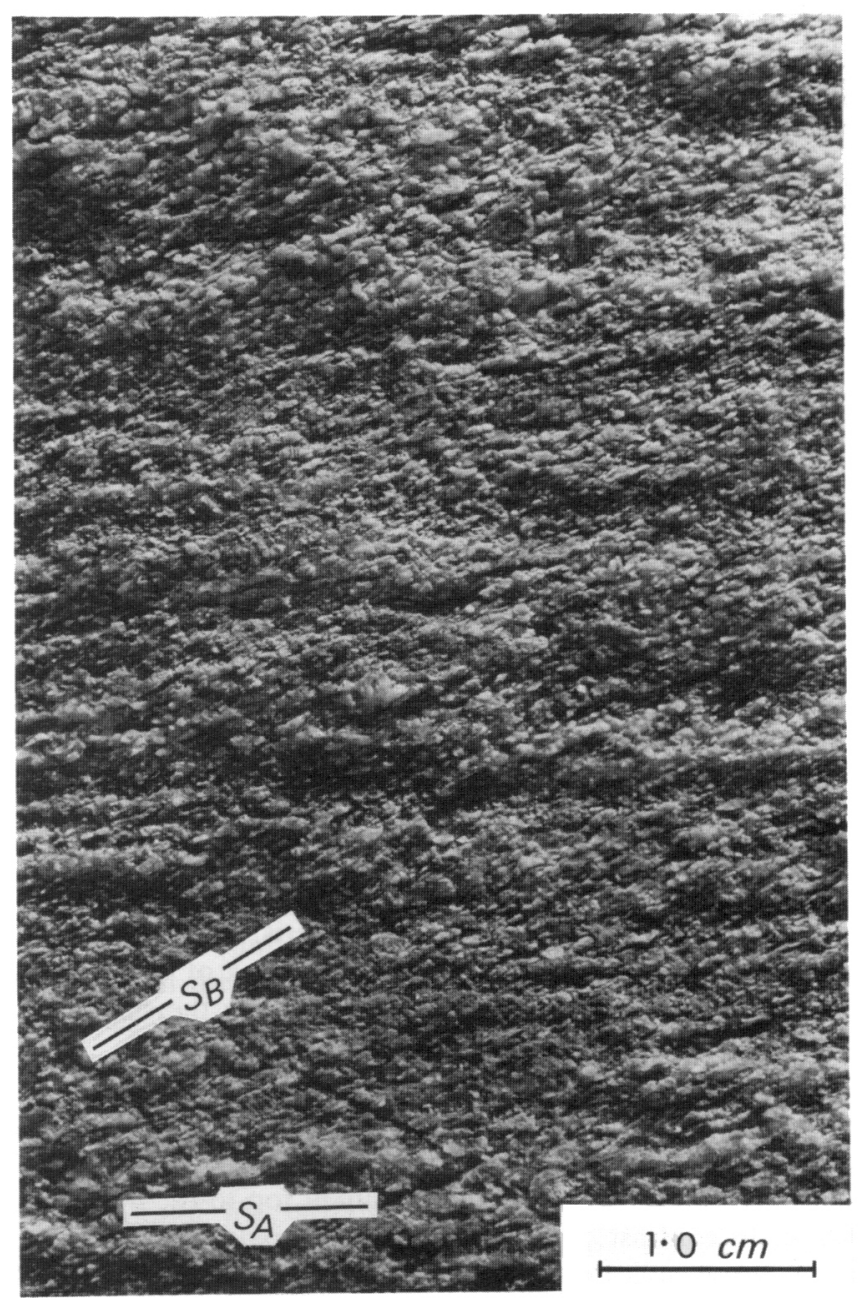

Figure 16 Elongate dynamically recrystallised calcite grains in Saline Valley marble defining a grain shape fabric $\left(S_{B}\right)$ which is oriented oblique to mylonitic foliation ( $\left.S_{A}\right)$-sample PF.240; exposure surface (viewed toward the $\mathrm{NE}$ ) is oriented subperpendicular to $\mathrm{S}_{\mathrm{A}}$ and parallel to stretching lineation; area shown measures $6 \mathrm{~cm} \times 4 \mathrm{~cm}$; sample collected at a structural height of approximately $70.0 \mathrm{~m}$ above the pluton margin; see Figure 15 for sample location. 
We consider the presence of a strongly-developed point maximum in the quartz c-axis fabrics in these tectonites (oriented within the mylonitic foliation plane perpendicular to lineation) to indicate relatively high temperatures of crystal plastic deformation. In deformation associated with regional metamorphism, such $\mathrm{Y}$-axis parallel point maxima are generally associated with at least amphibolite facies conditions (see review by Schmid \& Casey 1986). Relatively high deformation temperatures are also indicated by lobate quartz grain boundaries (particularly in the quartz veins), suggesting a high degree of grain boundary mobility during dynamic recrystallisation (Urai et al. 1986). Further supporting evidence for this inferred relatively high temperature of deformation is provided by preliminary calcite-dolomite geothermometry studies of marble from the Poleta Formation situated at distances of less than $12 \mathrm{~m}$ above the pluton margin. For the localities reported in this paper, minimum estimates for temperatures of metamorphism range between 380 and $540^{\circ} \mathrm{C}$ (Nyman \& Law, unpublished data, 1991).

We must also ask whether the deformation features observed within the gneissic border facies may have developed under magmatic conditions. Criteria for the identification of magmatic and tectonic foliations have recently been reviewed by Paterson et al. (1989). One crystal fabric criterion that may be applied is the presence or absence of quartz prism $\langle\mathbf{c}\rangle$ slip in association with igneous intrusions such as granites. Prism $\langle c\rangle$ slip, evidenced by a c-axis point maximum oriented sub-parallel to the stretching lineation, may indicate plastic deformation at temperatures near the granite solidus (Blumenfeld et al. 1986; Gapais \& Barbarin 1986; Blumenfeld \& Bouchez 1988). Deformation at least within the quartz veins from the gneissic border facies, however, is clearly dominated by lower temperature 〈a) slip (see reviews of slip system criteria by Schmid \& Casey 1986; Law 1990). No evidence for quartz $\langle c\rangle$ slip has been found within the rocks of the gneissic border facies. Similarly, no microstructural or chemical evidence for magmatic foliations have been observed within the pluton (Sylvester et al. 1978; Paterson et al. 1991a). Deformation within the gneissic border facies would clearly appear to have taken place in the solid state.

\subsection{Deformation models}

Any model for the deformation features associated with the Papoose Flat Pluton's gneissic border facies and surrounding aureole rocks must take into account the following observations:

(1) Intense crystal plastic deformation is restricted to the western part of the pluton and its surrounding aureole. In contrast, the eastern part of the pluton is characterised by discordant contacts at the pluton margin, lack of penetrative deformation features and hornfels textures in the surrounding country rocks (Sylvester et al. 1978).

(2) Mylonite formation in: (a) the quartzites and at least some marble layers within the aureole, and (b) quartz veins within the gneissic border facies, is clearly a plane strain deformation associated with a dominant top-to-the-SE shear sense. In contrast, only rarely are unequivocal examples of shear sense indicators observed within granitic rocks of the gneissic border facies (cf. Paterson et al. 1991a, p. 325).

(3) The pattern of quartz c-axis preferred orientation within both the mylonitic aureole rocks and quartz veins within the gneissic border facies indicates relatively high $\left(>450^{\circ} \mathrm{C}\right)$ temperatures of deformation.

Three deformation models, which are potentially consistent with the above observations, are illustrated in Figure 17.
In the first model (Fig. 17(a)) the granite forming the western part of the pluton was forcibly intruded in a northwestward direction from the pluton source as a nearly solidified wedge beneath a static cover of sedimentary rocks. In this model, sideways magmatic wedging toward the NW, rather that in situ ballooning associated with flattening
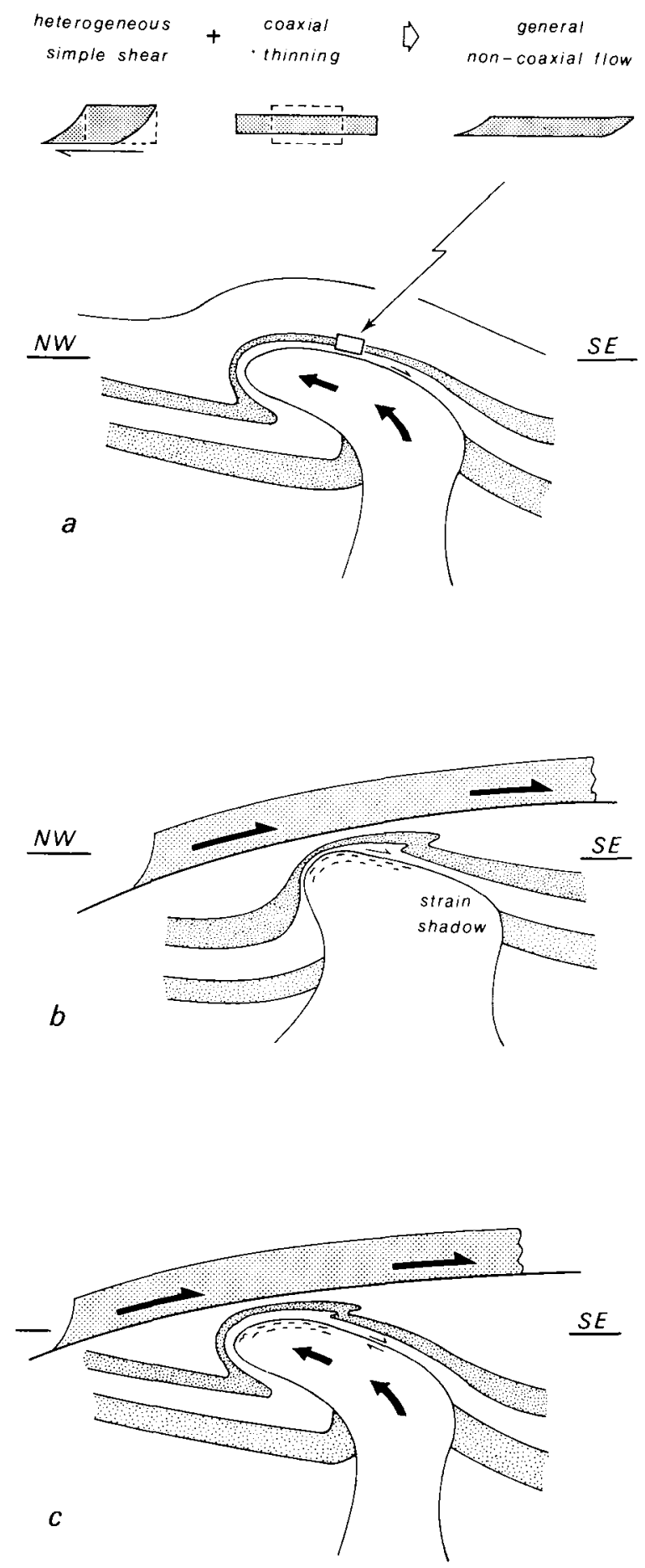

Figure 17 Diagrammatic explanation of tectonic models for the observed localisation of intense non-coaxial strain associated with crystal plastic deformation on the western part of the Papoose Flat Pluton and its metamorphic aureole.

(a) Strain due to "magmatic wedging": observed $90 \%$ thinning of individual stratigraphic units indicates that simple shear deformation must have been accompanied by layer parallel extension (i.e. coaxial thinning) unless the shear zone boundaries were oriented oblique to bedding.

(b) Regional SE-directed thrusting of cover rocks over the pluton.

(c) Combined "magmatic wedging" and regional overthrusting. 
strains in the cover rocks, is proposed. However, as recently pointed out by Paterson et al. (1991a), within the White and Inyo mountains a number of other plutons of similar age to the Papoose Flat Pluton also show more intense solid-state deformation on their western or northwestern margins than on their eastern margins. We agree with Paterson et al. (1991a) that it seems at least unlikely that so many of these Cretaceous-age plutons should all have been forcibly intruded towards the $\mathrm{W}$ or NW.

In the second model (Fig. 17(b)) the mylonitic deformation observed around the western margin of the Papoose Flat Pluton is associated with regional SE-directed thrusting of the cover rocks over the underlying pluton (Paterson et al. 1991a). A similar model for the late Cretaceous age Pellisier Flat Pluton, located in the northern part of the White-Inyo Range, was also proposed by Dunne et al. (1978). From study of foliation development around cordierite porphyroblasts in the Papoose Flat Pluton's aureole, Paterson et al. (1991a) suggested that much of the deformation may have occurred after pluton emplacement and associated contact metamorphism. Although the timing of deformation and pluton emplacement remains enigmatic, we maintain that the relatively high deformation temperatures $\left(>450^{\circ} \mathrm{C}\right)$ indicated by the quartz mylonite c-axis fabrics dictate that the pluton must have been acting as a heat source at the time of the proposed thrusting-related mylonite formation. Nowhere outside the pluton's aureole has evidence been found for either mylonite formation or amphibolite facies regional metamorphism. If the regional thrusting model (Fig. 17(b)) is applicable, then the over-riding thrust sheet must have been moving during the pluton's early stages of cooling.

Taken in conjunction with the quartz mylonite results reported in the present paper, we interpret the observation by Paterson $e t$ al. (1991a) that foliation development in the pelitic units of the pluton's aureole is (at least locally) syn-post cordierite porphyroblast growth, as an indication that thrusting may have occurred over an appreciable interval of the pluton's cooling history. In this model the high temperature crystal fabrics in the quartz mylonite are interpreted as recording a relatively early stage in the pluton's thrusting-related cooling history, whereas the post-cordierite deformation in the schistose units may be recording continued thrusting-related deformation at progressively lower temperatures during pluton cooling. Because the Papoose Flat Pluton has yielded K-Ar ages on biotite of 75-81 Ma (Kistler et al. 1965), these lines of argument clearly limit the postulated thrusting to be late Cretaceous in age. It should be borne in mind, however, that regional mapping (Nelson 1966, 1971; Ross 1965, 1967a,b) revealed only local evidence for thrusting within the strata of the Papoose Flat area. In contrast, considerable evidence for large-scale thrusting has been recorded in the northern part of the White-Inyo Range (e.g. Dunne et al. 1978; Hanson et al. 1987).

The third model (Fig. 17(c)) takes structural elements from both of the previously described models. In this compromise model, we envisage magmatic wedging as operating at the same time as regional overthrusting. With the evidence available, it is difficult to assess the merits of this compromise model in relation to the second model. One potentially fruitful line of future research may be to map out in detail the change in foliation orientation traced outward from the pluton. For example, as illustrated by Brun and Pons (1981) and Brun (1983, fig. 5), the pattern of foliation development at the pluton scale may be diagnostic of synchronous forcible pluton emplacement and regional overthrusting.

The apparently dominant coaxial nature of deformation within the granitic rocks of the pluton's gneissic border facies remains to be explained. One possibility is that the scarcity of unequivocal shear-sense indicators in the granitic gneiss reflects a rheological contrast between the feldsparrich granite and the rheologically weaker quartzite, marble and schist. As pointed out by Lister and Williams (1983, p. 13) a domainal distribution of materials with differing rheological properties within an evolving shear zone may result in strain path partitioning, strain accumulating coaxially in the rheologically stronger material while, at the same time, the weaker material undergoes non-coaxial flow. Alternatively, the inferred coaxial deformation in the gneissic border facies could reflect the influence of forcible pluton emplacement operating either during or before regional thrusting.

\section{Conclusions}

Microstructural and crystallographic fabric analysis indicates that mylonite formation around the western margin of the Papoose Flat Pluton is dominantly associated with plane strain deformation involving, in at least the pelitic and quartz-rich units, top-to-the-SE shearing. Crystal plastic deformation is restricted to the pluton's gneissic border facies and the overlying aureole rocks surrounding the western margin of the pluton. With the information presently available, these deformation features may be best explained by a tectonic model involving regional SEdirected thrusting of the cover rocks over the underlying pluton. This overthrusting may, or may not, have been accompanied by synchronous forcible emplacement of the underlying Papoose Flat Pluton. However, although the timing of deformation and pluton emplacement remains enigmatic, we maintain that the relatively high deformation temperatures $\left(>450^{\circ} \mathrm{C}\right)$ indicated by the c-axis fabrics within the mylonites dictate that the pluton must have been acting as a heat source at the time of the proposed thrusting-related mylonite formation. Nowhere outside the pluton and its aureole has evidence been found for either mylonite formation or equivalent temperature regional metamorphism. Therefore, if the regional thrusting model is applicable, then the over-riding thrust sheet must have been moving during the pluton's early stages of cooling.

\section{Acknowledgments}

This study was supported by: (1) National Science Foundation Grant EAR-9018929 to Law and Sylvester, (2) a grant from the Creative Match Grants Program of Virginia Tech to Law, and (3) a Sigma Xi grant to Morgan. The authors wish to express their gratitude to Clem Nelson for his continued support during the course of this work, and to Robert Miller for his constructive review of an earlier version of the manuscript. Law particularly wishes to thank Rick Sibson for introducing him to the geology of the Papoose Flat Pluton and for providing logistic support during the early stages of the project.

\section{References}

Anovitz, L. M. \& Essene, E. J. 1987. Phase equilibria in the system $\mathrm{CaCa}_{3}-\mathrm{MgCO}_{3}-\mathrm{FeCO}_{3}$. J PETROL 28, 389-414.

Bateman, P. C., Clark, L. C., Huber, N. K., Moore, J. G. \& Rinehart, C. D. 1963 . The Sierra Nevada batholith: a synthesis 
of recent work across the central part. US GEOL SURV PROF PAP 414-D.

Bateman, R. 1984. On the role of diapirism in the segregation, ascent and final emplacement of granitoids. TECTONOPHYSICS 110, 211-31.

Blumenfeld, P. \& Bouchez, J.-L. 1988. Shear criteria in granite and migmatite deformed in the magmatic and solid states. J STRUCT GEOL 10, 361-72.

Blumenfeld, P., Mainprice, D. \& Bouchez, J. L. 1986. C-slip in quartz from subsolidus deformed granite. TECTONOPHYSICS 127, 97-115.

Bouchez, J.-L., Lister, G. S. \& Nicolas, A. 1983. Fabric asymmetry and shear sense in movement zones. GEOL RDSCH 72, 401-19.

Brun, J. P. 1983. L'origine des domes gneissiques: modeles et tests. BULL GEOL SOC FRANCE 25, 219-26.

Brun, J. P. \& Pons, J. 1981. Strain patterns of pluton emplacement in a crust undergoing non-coaxial deformation. J STRUCT GEOL 3, 219-29.

Brun, J. P., Gapais, D., Cogne, J. P., Ledru, P. \& Vigneresse, J. L. 1990. The Flamanville Granite (NW France): an unequivocal example of a syntectonically expanding pluton. GEOL J 25, 271-86.

Casey, M. 1981. Numerical analysis of X-ray texture data: an implementation in FORTRAN allowing triclinic or axial specimen symmetry and most crystal symmetries. TECTONOPHYSICS 78, 51-64.

Castro, A. 1986. Structural pattern and ascent model in the Central Extramadura batholith, Hercynian belt, Spain. J STRUCT GEOL 8, 645-63.

Courrioux, G. 1987. Oblique diapirism: the Criffel granodioritegranite zoned pluton (SW Scotland). J STRUCT GEOL 9, $313-30$

Dunne, G. C., Gulliver, R. M. \& Sylvester, A. G. 1978. Mesozoic evolution of rocks of the White, Inyo, Argus, and Slate ranges, eastern California. In Howell, D. G. \& McDougall, K. A. (eds) Mesozoic paleogeography of the western United States. Pacific Section, Society of Economic Paleontologists and Mineralogists, Pacific Coast Paleogeography Symposium 2, 189-208, Los Angeles, California.

Etchecopar, A. \& Vasseur, G. 1987. A 3-D kinematic model of fabric development in polycrystalline aggregates: comparisons with experimenial and natural examples. J STRUCT GEOL 9, 705-17.

Gapais, D. \& Barbarin, B. 1986. Quartz fabric transition in a cooling syntectonic granite (Hermitage Massif, France). TECTONOPHYSICS 125, 357-70.

Godin, P. D. \& Paterson, S. R. 1991. Re-evaluation of a blistering pluton: post-emplacement regional deformation at the Cretaceous Papoose Flat Pluton, White-Inyo Mountains, California. GEOL SOC AM ABSTR 23(2), A29.

Guineberteau, B., Bouchez, J.-L. \& Vignneresse, J.-L. 1987. The Mortagne granite pluton (France) emplaced by pull-apart along a shear zone: structural and gravimetric arguments, regional implication. BULL GEOL SOC AM 99, 763-70.

Hanmer, S. \& Passchier, C. 1991. Shear-sense indicators: a review. Geological Survey of Canada, Paper 90-17. Ottawa: Ministry of Supply and Services.

Hanson, R. B., Saleeby, J. B. \& Fates, D. G. 1987. Age and tectonic setting of Mesozoic metavolcanic and metasedimentary rocks, northern White Mountains, California. GEOLOGY 15, 1074-78.

Hibbard, M. J. 1987. Deformation of incompletely recrystallised magma systems: granite gneisses and their tectonic implications. J GEOL 95, 543-61.

Hollister, L. \& Crawford, M. L. 1986. Melt enhanced deformation: a major tectonic process. GEOLOGY 14, 558-61.

Hutton, D. W. 1982. A tectonic model for the emplacement of the Main Donegal granite, NW Ireland. J GEOL SOC LONDON 139, 615-31.

Hutton, D. W. 1988a. Granite emplacement mechanisms and tectonic controls: inferences from deformation studies. TRANS R SOC EDINBURGH EARTH SCI 79, 245-55.

Hutton, D. W. 1988b. Igneous emplacement in a shear zone termination: the biotite granite at Strontian, Scotland. BULL GEOL SOC AM 100, 779-94.

Jessell, M. W. 1988. Simulation of fabric development in recrystallizing aggregates-II: example model runs. J STRUCT GEOL 10, 779-94.

Kistler, R. W., Bateman, P. C. \& Branock, W. W. 1965. Isotopic ages of minerals from granitic rocks of the central Sierra Nevada and Inyo Mountains. BULL GEOL SOC AM 76,
$155-64$

Knipe, R. J. \& Law, R. D. 1987. The influence of crystallographic orientation and grain boundary migration on microstructural and textural evolution in a S-C mylonite. TECTONOPHYSICS 135, 155-69.

Law, R. D. 1990. Crystalographic fabrics: a selective review of their applications to research in structural geology. In Knipe, R. J. \& Rutter, E. H. (eds) Deformation mechanisms, rheology and tectonics. SPEC PUBL GEOL SOC LONDON 54, 335-52.

Law, R. D., Knipe, R. J. \& Dayan, H. 1984. Strain path partitioning within thrust sheets: microstructural and petrofabric evidence from the Moine thrust zone at Loch Eriboll, northwest Scotland. J STRUCT GEOL 6, 477-97.

Law, R. D., Casey, M. \& Knipe, R. J. 1986. Kinematic and tectonic significance of microstructures and crystallographic fabrics within quartz mylonites from the Assynt and Eriboll regions of the Moine thrust zone, NW Scotland. TRANS R SOC EDINBURGH EARTH SCI 77, 99-123.

Law, R. D., Morgan, S. S. \& Sylvester, A. G. 1990. Evidence for large scale shearing during emplacement of the Papoose Flat Pluton, California: a re-examination of the microstructures and crystallographic fabrics. GEOL SOC AM ABST 22(7), A183.

Lister, G. S. \& Hobbs, B. E. 1980. The simulation of fabric development during plastic deformation: the effect of deformation history. J STRUCT GEOL 2, 355-70.

Lister, G. S. \& Snoke, A. 1984. S-C mylonites. J STRUCT GEOL 6, 617-38.

Lister, G. S. \& Williams, P. F. 1983. The partitioning of deformation in flowing rock masses. TECTONOPHYSICS $\mathbf{9 2}$, $1-33$.

Morgan, S. S., Law, R. D. \& Sylvester, A. G. 1991. Strain-path partitioning during contact metamorphism and emplacement of the Papoose Flat pluton, eastern California. GEOL SOC AM ABSTR PROG 23(5), A175.

Nelson, C. A. 1962. Lower Cambrian-Precambrian succession, White Inyo Mountains, California. BULL GEOL SOC AM 73, $139-44$

Nelson, C. A. 1966. Geologic map of the Waucoba Mountain quadrangle, Inyo County, California. U.S. Geological Survey Quadrangle Map GQ-528, scale 1:62,500. Reston, Virginia: U.S. Geological Survey.

Nelson, C. A. 1971. Geologic map of the Waucoba Spring quadrangle, Inyo County, California. U.S. Geological Survey Quadrangle Map GQ-921, scale 1:62,500. Reston, Virginia: U.S. Geological Survey.

Nelson, C. A., Oertel, G., Christie, J. M. \& Sylvester, A. G. 1977. Geologic map, structure sections and palinspastic map of the Papoose Flat pluton, Inyo Mountains, California. GEOL SOC AM MAP \& CHART SERIES MC-20.

Paterson, S. R., Vernon, R. H. \& Tobisch, O. T. 1989. A review of criteria for the identification of magmatic and tectonic foliations in granitoids. J STRUCT GEOL 11, 349-63.

Paterson, S. R., Brudos, T., Fowler, K., Carlson, C., Bishop, K. \& Vernon, R. H. 1991a. Papoose Flat Pluton: forceful expansion or postemplacement deformation. GEOLOGY 19, 324-7.

Paterson, S. R., Vernon, R. H. \& Fowler, T. K. 1991b. Aureole tectonics. REV MINERAL 26, 673-722.

Paterson, S. R. \& Tobisch, O. T. 1988. Using pluton ages to date regional deformations: problems with recently used criteria. GEOLOGY 16, 1108-11.

Price, G. P. 1985. Preferred orientations in quartzites. In Wenk, H.-R. (ed.) Preferred orientations in deformed deformed metals and rocks: an introduction to modern texture analysis, 385-406. Orlando: Academic Press.

Ramsay, J. G. 1989. Emplacement kinematics of a granite diapir: the Chindamora batholith, Zimbabwe. J STRUCT GEOL 11, 191-209.

Rice, J. M. 1977. Contact metamorphism of impure dolomite limestone in the Boulder aureole, Montana. CONTRIB MINERAL PETROL 59, 237-59.

Ross, D. C. 1965. Geology of the Independence quadrangle, Inyo County, California. BULL US GEOL SURV 1181-0, 64.

Ross, D. C. 1967a. Geologic map of the Waucoba Wash quadrangle, Inyo County, California. U.S. Geological Survey, Geological Quadrangle Map GQ-612, scale 1:62,500.

Ross, D. C. 1967b. Generalised map of the Inyo Mountains region. U.S. Geological Investigations Map I-506, scale 1:125,000.

Ross D. C. 1969. Description petrography of three large granitic bodies in the Inyo Mountains, California. U.S. Geological Survey, Professional Paper $601,47 \mathrm{p}$

Schmid, S. M., Panozzo, R. \& Bauer, S. 1987. Simple shear experiments on calcite rocks: rheology and microfabric. J 
STRUCT GEOL 9, 747-78.

Schmid, S. M. \& Casey, M. 1986. Complete fabric analysis of some commonly observed quartz c-axis patterns. In Heard, H. C. \& Hobbs, B. E. (eds) Mineral and Rock Deformation: Laboratory Studies, the Paterson Volume. AM GEOPHYS UNION, GEOPHYS MONOGR 36, 263-86.

Simpson, C. 1986. Determination of movement sense in mylonites. J GEOL EDUC 34, 246-61

Simpson, C. \& Schmid, S. M. 1983. An evaluation of criteria to deduce the sense of movement in sheared rocks. BULL GEOL SOC AM 94, 1281-8.

Starkey, J. 1989. Microcomputer Workshop: Quantitative Petrofabric Analysis, 9th Annual Meeting, Structural Geology \& Tectonics Division, Geological Association of Canada, London, Ontario, Canada.

Sylvester, A. G. 1966. Structural and metamorphic petrology of the contact aureole of the Papoose Flat Pluton, Inyo Mountains, California. Unpublished Ph.D. thesis, University of California at Los Angeles.

Sylvester, A. G. 1969. A Microfabric study of calcite, dolomite and quartz around the Papoose Flat Pluton, California. BULL GEOL SOC AM 80, 1311-28.
Sylvester, A. G., Oertel, G., Nelson, C. A. \& Christie, J. M. 1978. Papoose Flat pluton: a granitic blister in the Inyo Mountains, California. BULL GEOL SOC AM 89, 1205-19.

Sylvester, A. G. \& Babcock, J. W. 1975. Significance of multiphase folding in the White-Inyo range, eastern california. GEOL SOC AM ABSTR PROG 7, 1289.

Sylvester, A. G. \& Christie, J. M. 1968. The origin of crossed-girdle orientations of optic axes in deformed quartzites. J GEOL 76, $571-80$.

Tullis, J., Christie, J. M. \& Griggs, D. T. 1973. Microstructures and preferred orientations of experimentally deformed quartzites. BULL GEOL SOC AM 84, 297-314.

Urai, J. L., Means, W. D. \& Lister, G. S. 1986. Dynamic recrystallization of minerals. In Heard, H. C. \& Hobbs, B. E. (eds) Mineral and rock deformation: laboratory studies, the Paterson Volume. AM GEOPHYS UNION, GEOPHYS MONOGR 36, 161-99.

Wenk, H.-R., Takeshita, T., Bechler, E., Erskine, B. G. \& Matthies, S. 1987. Pure shear and simple shear calcite textures. Comparison of experimental, theoretical and natural data. J. STRUCT GEOL 9, 731-46.

R. D. LAW, S. S. MORGAN \& M. NYMAN, Department of Geological Sciences, Virginia Polytechnic Institute \& State University, Blacksburg, Virginia 24061, U.S.A.

M. CASEY, Geologisches Institut, ETH-Zentrum, Zurich CH 8092, Switzerland

A. G. SYLVESTER, Department of Geological Sciences, University of California at Santa Barbara, Santa

Barbara, California 93106 , U.S.A. 